\title{
Validation of a questionnaire for the detection of children at high risk of developmental disorders. The PRUNAPE Pre-Screening Test
}

\author{
Horacio Lejarraga, M.D. ${ }^{a}$, Diana Kelmansky, M.D. ${ }^{a}$, Celina Lejarraga, M.D. ${ }^{a}$, \\ Gabriela Charrúa, M.D. ${ }^{a}$, Graciela Salamanco, M.D. ${ }^{b}$, Iván Insúa, M.D. ${ }^{a}$, \\ and Fernando Nunes, M.D. ${ }^{a}$
}

\begin{abstract}
Introduction.The administration of the National Screening Test (PruebaNacional de Pesquisa, PRUNAPE), a tool which is effective to screen inapparent developmental disorders in children under 6 years old, requires adequate training, time, space and furniture. A simplequestionnaire to help screen large population groups could be useful to identify children at risk.

Objective.To evaluate the validity of the PRUNAPE pre-screening questionnaire (cuestionario PRUNAPE pre-pesquisa, CPPP) to identify children at risk of not passing the test. Methods.Fifty seven PRUNAPE milestones were transformed into questions; they were organized in five questionnaires (one for each age group between 6 and 71 months old) with illustrative pictures. The study was performed in Florencio Varela and in the Health PromotionUnit of Hospital de Niños "Ricardo Gutiérrez" in the Autonomous City of Buenos Aires. In a sample of 533 healthy children and their mothers, of a low socioeconomic level, the CPPP was consecutively: a) self-administered by each mother (CPPP-SA), b) by healthcare personnel (CPPP-HP), and finally, c) the PRUNAPE test was administered to each child by qualified professionals. Each step was performed by a different professional in a tripleblind fashion. When choosing the cutoff point, the positive predictive value (PPV) was prioritized to reach the least possible number of false positives. Results.For the CPPP-SA and the CPPP-HP, the overall results were, respectively: Cohen's kappa coefficient: 0.23 and 0.28 ; sensitivity: 0.41 and 0.42 ; specificity: 0.81 and 0.85 ; negative predictive value 0.57 and 0.59 ; and PPV 0.71 and 0.76 .

Conclusions.The CPPP is a valid tool to identify children who most require the PRUNAPE to be administered.

Key words: developmental disorders, screening test, PRUNAPE, pre-screening questionnaire, child development.
\end{abstract}

http:/ /dx.doi.org/10.5546/aap.2013.476

Horacio Lejarraga,

M.D.: cursotesis07@

gmail.com

Conflict of interest:

None.

Received: 2-2-2013

Accepted: 6-19-2013 under 6 years old. ${ }^{1}$ It is duly validated, has been recommended by the Committee of Outpatient Pediatrics of the Argentine Society of Pediatrics, ${ }^{2}$ and is widely used in different settings. However, its administration requires personnel to be trained, available time and adequate space and furniture. Considering the social programs that cover a large number of families and children, like Plan Nacer, it would be appropriate to do a pre-screening targeted to mothers or guardians with a simpler method which pre-screens children with the highest likelihood of not passing the PRUNAPE test, so that the screening process of children who might be candidates to this test, and eventually also specific diagnoses and interventions, are more cost-effective.

An alternative is to interview parents and ask them at what age their children attained the developmental milestones (retrospective questions), but this approach has proved not to be so reliable. ${ }^{3,4}$ Another more reliable and cost-effective approach is the use of simple questionnaires for parents ${ }^{5}$ about what the child can do at the time of the interview.

The objectives of this article are: 1) to evaluate the validity of the prescreening PRUNAPE test (cuestionario PRUNAPE pre-pesquisa, CPPP) to identify children with the highest risk of not passing the test; 2 ) to evaluate if the validity is different if administered by mothers or by the healthcare personnel, and 3) taking into account that low birth weight is related to a higher prevalence of developmental disorders, to perform a subset analysis 
for children with a birth weight of less than $2500 \mathrm{~g}$ to see if this outcome measure can also predict PRUNAPE results.

\section{MATERIAL AND METHODS}

The study was conducted from July $2^{\text {nd }}$ to August $31^{\text {st }}$ in the Department of Health Protection and Promotion of Hospital de Niños Ricardo Gutiérrez and in community centers of Florencio Varela (FV) with the participation of its Secretariat of Health. Mothers and their children were visited at their homes by health promoters and evaluated in: Sociedad de Fomento 17 de Diciembre, San Nicolás; Cooperación de Barrio Parque, Villa Mónica; Cooperativa 20 de Diciembre, Villa Argentina; and Centro de Integración Comunitaria Pico de Oro.

\section{Preparation of the questionnaire}

The general recommendations for questionnaires established by the Ministry of Health were followed. ${ }^{6}$ PRUNAPE milestones were transformed into simple questions for mothers about what the child is able to do, avoiding ambiguous questions. For instance, based on the PRUNAPE milestone "sitting unsupported," the following question was generated: "Is the child able to sit alone, without the support of his/her hands?" No questions were formulated for children under 6 months old because the prevalence of developmental disorders is low in this age range in relation to older ages. ${ }^{7}$

\section{Fields of work}

Community health promoters visited low socio-economic households and summoned mothers, on an individual basis, to participate. Once the consent was signed, Florencio Varela mothers and their children where driven to Neighborhood Cooperation Centers for the studies to be conducted.

\section{Assessment of the comprehension of questionnaire texts}

Forty six mothers whose children were healthy (from 6 to 71 months old) were interviewed; all of them were of a low socio-economic level. None of them participated in the final validation sample. Based on previous experiences, ${ }^{8}$ mothers were invited to complete the questionnaire and to participate in a focus group meeting according to the corresponding age group their children belonged to. The following items were assessed on a qualitative and quantitative basis: a) comprehension and interpretation of questions by mothers with their children present, $b$ ) usefulness of illustrative pictures, c) adequacy of questions to prompt yes/no answers.

\section{Questionnaires}

Five questionnaires were developed, one for each age range. Fifty seven out of a total of 64 PRUNAPE milestones for children older than 6 months were made ( $89 \%$ of possible questions) oriented towards asking about competencies a child can attain. Since the seven remaining milestones were rather complex, it was not possible to convert them to questions.

The five questionnaires have the same cover page (please, refer to electronic version) with healthcare information. The possible answers to each question are "Yes," "No," or "I don't know / Does not cooperate." Both this latter answer and a "No" answer are afterwards classified as "Does not meet expectations." Questionnaires 4 and 5 have some simple tests for either the mother or the healthcare personnel to administer to the child: recognize colors, jump, recognize figures or draw. The pass or fail criterion of the questionnaire is explained at the end of each form: the child is considered to fail if he/she does not answer one or two questions whose PRUNAPE $90^{\text {th }}$ percentile (or $75^{\text {th }}$, according to the questionnaire) is less than the child's age. It is not required to adjust the child's age to the gestational age. The access to the five questionnaires is open from the e-version of this article.

In all cases, both for the questionnaires administered by the healthcare personnel (HP) as well as those self-administered (SA), the final decision related to the child passing or failing the test should be made by healthcare personnel who is well aware of the Technical Handbook that comes with the CPPP. This handbook (and the questionnaires) can be downloaded from the Acumar health website www.acumar.gov.ar (only spanish version).

\section{Concomitant validation}

Once questions were reformulated and the design was adjusted, the next step was to evaluate how much the questionnaire was able to predict PRUNAPE results. The guidelines used were followed to validate the test; ${ }^{9}$ based on the previous experience of validation, it was considered reasonable to include 100 children in each of the five questionnaires (see below); 
therefore, a sample of 500 children was estimated, but eventually a $10 \%$ was added (a total of 550 children) to make up for possible losses.

The study consisted of three consecutive steps: 1) self-administration of the questionnaire by mothers (questionnaire CPPP-SA); 2) administration of the same questionnaire by healthcare professionals (psychologist, educational psychologist or pediatrician) (questionnaire CPPP-HP); 3) administration of the PRUNAPE to the child. The procedure was always carried out following the above order. A total of 15 professionals participated (pediatricians, psychologists and educational psychologists), who had all been previously trained in the administration of the PRUNAPE. The three procedures were blinded, each of the three steps was done by a different professional without anyone knowing the result of the other two attempts. Each professional had a laptop with electronic versions of the questionnaires and the PRUNAPE so as to be able to record the information in the field. A professional of the healthcare team recorded the answers of the CPPP-SA questionnaires (in paper) in the laptops, in the same place where the survey was performed. In addition to the questions, the questionnaire had information about the mothers' education, country of origin, the child's date of birth and birth weight.

\section{Statistical studies}

The assessment was done with the following indicators used for validations of other tools: percent agreement, Cohen's kappa coefficient, sensitivity, specificity, negative predictive value (NPV) and positive predictive value (PPV). ${ }^{9}$ Cutoff points were chosen prioritizing the specificity and the positive predictive value so as to avoid the maximum possible number of false positives, and they were the same for both questionnaire modalities (SA and HP).

\section{Validation indicators with a high and a low prevalence of developmental disorders}

From all the indicators used, some are independent of the prevalence o the problem encountered in the field, others are not. Sensitivity and specificity exclusively depend on the instrument, but the predictive value(positive and negative) depends on the prevalence of the problem. For instance, if the indicators of three hypothetical samples with different prevalence of children who failed the PRUNAPE (with a prevalence of $53.3 \%, 99 \%$ and $1.1 \%$, respectively) were estimated for the same instrument, i.e., with the same sensitivity and specificity (e.g. 0.82 and 0.43 , respectively), positive predictive values would be $0.73,0.996$ and 0.03 , in this order. The greater the prevalence of the problem, the higher the predictive value of the tool.

\section{RESULTS}

\section{Sample characteristics}

The final sample (Table 1) on which the validation was made consisted of 533 children and mothers, 487 from Florencio Varela. The 46 children from Hospital Gutiérrez were under 18 months old. The age range of the children included in the sample was from 0.50 to 5.99 years, matching the selection criterion. Seventeen mothers were born in Bolivia, 52 in Paraguay and 15 in Peru. Mothers without formal education were not able to fill in the self-administered questionnaire. There was no information about 6 mothers, but they knew how to read and write.

Aiming at determining whether there were any queries with a quite different matching percentage compared to the rest, the proportion of those whose result matched or did not match the corresponding PRUNAPE milestone was studied. Figure 1 shows matching percentages among questions included in the questionnaires and their corresponding PRUNAPE milestone. A question of questionnaire 3 had fewer matches than the rest. When removing it, there were no remarkable changes in the validation results; therefore, the decision was made not to remove it.

\section{Validation}

Table 2 shows the results of indicators as per the cutoff points selected for each of the five questionnaires, in A and PS modalities.

Nearly all the indicators for CPPP-HP questionnaires (administered by the healthcare personnel) were slightly better than for the CPPPSA questionnaires (self-administered), but this difference was small and non-systematic.

The CPPP-SA questionnaire had a low sensitivity in the 6 to 29 months age group and was higher in 30 months old children and older. Overall, the specificity $(\mathrm{Sp})$ ranged from 0.73 to 0.91 , the sensitivity (S) ranged from 0.25 to 0.53 , and the PPV ranged from 0.63 to 0.82 ; all of these were expected results takinginto account that the sensitivity and the PPV were prioritized.

In the CPPP-HP, the Sp, S and PPV values ranged from 0.84 to $0.91,0.25$ to 0.58 , 
and 0.64 to 0.90 , respectively. No significant differences were found in the validation values of the questionnaires among mothers with a primary and secondary education level.

\section{Birth weight and PRUNAPE}

In the 530 children whose birth weight (BW) was available, the mean weight was $3281 \mathrm{~g}$
(SD $580 \mathrm{~g}$, ranging from 1100 to $4650 \mathrm{~g}$ ). There was $8.4 \%$ of children with a BW $<2500 \mathrm{~g}$ and $1.5 \%$ with a BW $<1500 \mathrm{~g}$. Table 3 shows the proportion of children with a birth weight of less than $2500 \mathrm{~g}$ and of $1500 \mathrm{~g}$ that passed or failed the PRUNAPE. Of the children who failed the test, $73.3 \%$ had a low birth weight and $51.3 \%$ had an adequate birth weight. There is a significant difference in

TABLE 1. Sample characteristics and number of children and mothers studied per questionnaire

Total

Origin

Nationality of mothers

Maternal level of education

Birthweight

Age groups

$\begin{array}{cc}\text { Mothers/children } & 533 \\ \text { Florencio Varela } & 487 \\ \text { Hospital R. Gutiérrez } & 46 \\ \text { Argentina } & 449 \\ \text { Other } & 84 \\ \text { None } & 2 \\ \text { Primary } & 217 \\ \text { Secondary } & 277 \\ \text { University } & 31 \\ \text { 2500 g or more } & 249 \\ <2500 \text { g (<1500 g) } & 33(5) \\ \text { rm 1 (6-11 months old) } & 75 \\ \text { rm 2 (12-17 months old) } & 73 \\ \text { rm 3 (18-29 months old) } & 126 \\ \text { rm 4 (30-47 months old) } & 128 \\ \text { orm 5 (48-71 months old) } & 131\end{array}$

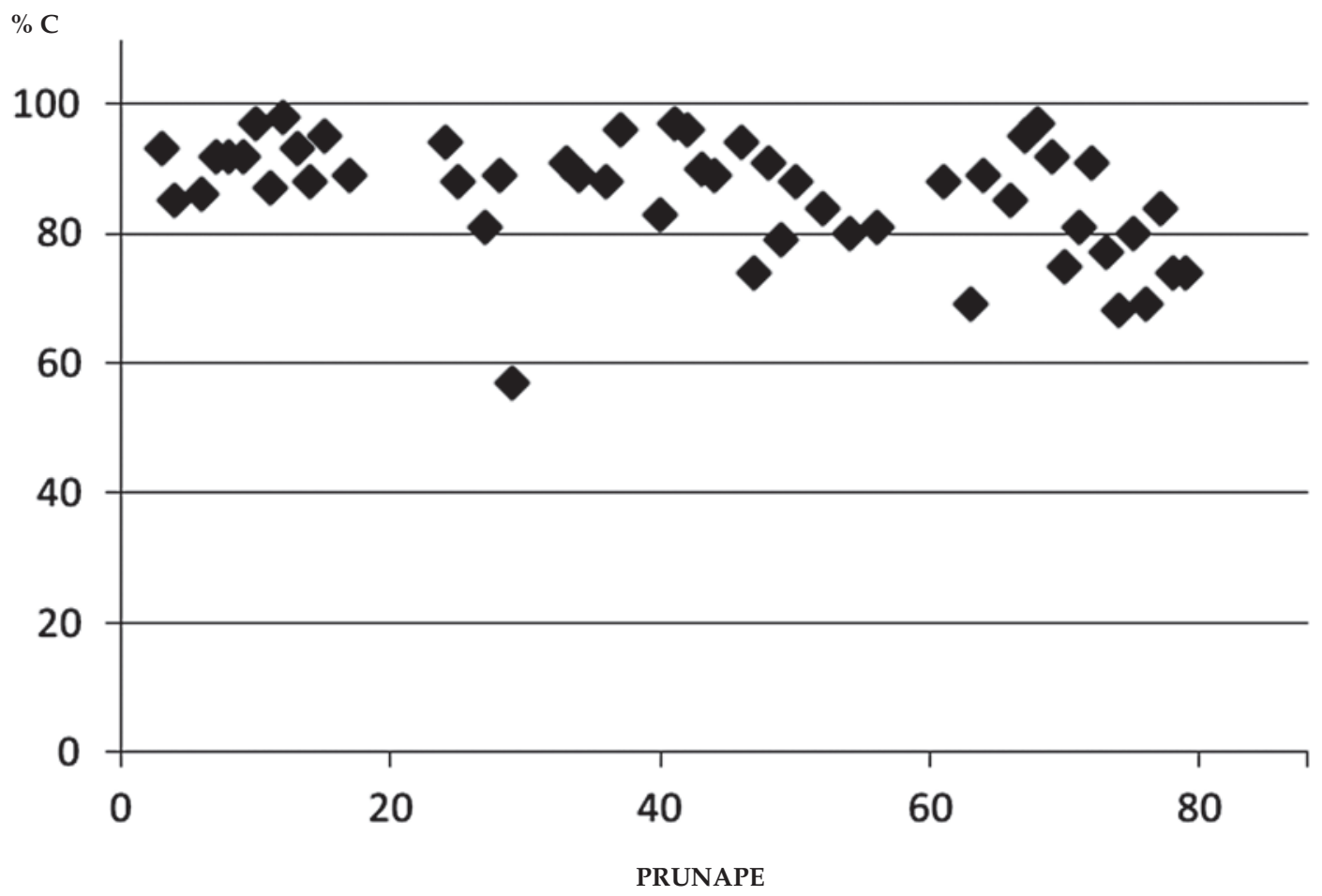


these percentages $(p<0.01)$. Table 3 shows the validation indicators that result if, instead of applying the questionnaire, low birth weight and very low birth weight are considered the risk criteria of failing the PRUNAPE. A very high specificity, even higher than that obtained in the CPPP questionnaire, and a high PPV are observed.

\section{DISCUSSION}

In the present study, we were able to validate a simple questionnaire to identify more accurately children who are candidates to the PRUNAPE. The lack of significant differences in the validity between the CPPP administration by mothers or the healthcare personnel, or among mothers of a different education level, makes it a very operational tool in primary care.

Questionnaire validity is very variable in the bibliography. For instance, Frankenburg obtained a sensitivity of $0.25 \%$ in the one developed to select children to administer the Denver test. ${ }^{10-11}$

Although the sensitivity of our questionnaires is not very high, in average it is slightly higher than 0.40 . This is because cutoff points were selected prioritizing the PPV in terms of having the least possible false positive results. Consequently, the PPV of our questionnaire is high, between 0.63 and 0.90 according to the questionnaire used, values that are comparable to the 0.23 of the Denver questionnaire ${ }^{11}$ and the ASQ questionnaire of 0.40 in a study, ${ }^{13}$ and of 0.20 in another one. ${ }^{12}$

TABLE 2.Validation indicators of each questionnaire type, SA (self-administered) and HP (healthcare personnel) based on the cutoff points selected to be used in primary care

\begin{tabular}{|c|c|c|c|c|c|c|c|c|}
\hline Type of administration & Questionnaire no. & Failure criterion & MP & Kappa & $\mathrm{Sp}$ & $\mathrm{S}$ & NPV & PPV \\
\hline Self-administered & 1 & 2 - P90 & 0.67 & 0.30 & 0.77 & 0.53 & 0.69 & 0.63 \\
\hline Healthcare personnel & & & 0.67 & 0.28 & 0.88 & 0.38 & 0.66 & 0.71 \\
\hline Self-administered & 2 & 2 - P75 & 0.66 & 0.18 & 0.91 & 0.25 & 0.66 & 0.64 \\
\hline Healthcare personnel & & & 0.66 & 0.18 & 0.91 & 0.25 & 0.66 & 0.64 \\
\hline Self-administered & 3 & 2 - P75 & 0.59 & 0.21 & 0.81 & 0.41 & 0.54 & 0.72 \\
\hline Healthcare personnel & & & 0.56 & 0.16 & 0.88 & 0.29 & 0.52 & 0.74 \\
\hline Self-administered & 4 & 1 - P90 & 0.58 & 0.19 & 0.73 & 0.52 & 0.38 & 0.82 \\
\hline Healthcare personnel & & & 0.66 & 0.33 & 0.84 & 0.58 & 0.45 & 0.90 \\
\hline Self-administered & 5 & 2 - P75 & 0.63 & 0.26 & 0.83 & 0.43 & 0.60 & 0.72 \\
\hline Healthcare personnel & & & 0.72 & 0.43 & 0.85 & 0.58 & 0.67 & 0.79 \\
\hline Self-administered & General & & 0.63 & 0.23 & 0.81 & 0.43 & 0.57 & 0.71 \\
\hline Healthcare personnel & & & 0.65 & 0.28 & 0.85 & 0.42 & 0.59 & 0.76 \\
\hline
\end{tabular}

Self-administered ( $\mathrm{n}=531)$; administered by the healthcare personnel $(\mathrm{n}=533)$.

MP: matching percentage; kappa: Cohen's kappa coefficient; Sp: specificity; S: sensitivity; NPV: negative predictive value;

PPV: positive predictive value.

Failure criteria:

2 - P90: the child does not answer two questions whose PRUNAPE 90th percentile is less than the child's age.

2 - P75: the child does not answer two questions whose PRUNAPE 75th percentile is less than the child's age.

1 - P90: the child does not meet a milestone whose PRUNAPE 90th percentile is less than the child's age.

TABLE 3. Percentage of children who fail the PRUNAPE, according to birth weight and validity indicators

\begin{tabular}{lcccccccc}
\hline BW & Fails & Passes & MP & Kappa & Sp & S & NPV & PPV \\
\hline$<2500 \mathrm{~g}$ & 33 & 12 & 0.51 & 0.07 & 0.95 & 0.13 & 0.49 & 0.73 \\
$\geq 2500 \mathrm{~g}$ & 249 & 236 & & & & & 0.13 \\
$<1500 \mathrm{~g}$ & 5 & 1 & 0.48 & 0.01 & 0.996 & 0.03 & 0.47 \\
$\geq 1500 \mathrm{~g}$ & 277 & 247 & & & & & \\
\hline
\end{tabular}

MP: matching percentage; kappa: Cohen's kappa coefficient; Sp: specificity; S: sensitivity; NPV: negative predictive value; PPV: positive predictive value. 
In China, a good reliability was found in parents' opinion regarding their children's potential developmental disorders, ${ }^{14}$ but in Australia, Coghland obtained a matching kappa value of $0.40,{ }^{15}$ which statisticians consider quite poor. ${ }^{9}$

The sensitivity is low in questionnaires 1 and 2 but then it increases in children of older ages. It is worth mentioning that when referring to a SP of $0.25,25 \%$ of the most severe cases of inapparent developmental disorders are being selected. As with the other tests, ${ }^{1-11}$ questions for children under 6 months old have not been included so that the questionnaire is more cost-effective.

The low birth weight (BW) provides such validation results that we consider the PRUNAPE could be administered without the need of administering the questionnaire.

In a previous study, ${ }^{7}$ no significant relationship was found between BW and PRUNAPE results. The difference could be due to the fact that this result was the consequence of a logistic regression in which the predictive capacity of the weight adjusted to all the other variables perhaps is "weakened." One of the variables to which it was adjusted was "pathologic pregnancy." which is strongly related to the birth weight. However, in the present study, the weight is not adjusted to any other outcome measure and perhaps it is subsuming in itself all the risk factors that overall make BW be associated to PRUNAPE failure in the setting where it was studied. In primary care this oversimplification of risk factors is good because the implementation of action guidelines and priorities to administer the test is easier.

In the past, the validation of specific questionnaires developed to detect different types of developmental problems (delays in motor development, language, cognitive development; autism; etc.) was examined by means of instruments based on questions to parents, with quite variable results. ${ }^{16-20}$

The detection of many developmental problems in pediatricians' offices is mainly achieved because of parents' concern. In this case, variability is also wide; some studies show that the rate of parents who show concern about any aspect of the development of their children is as high as $90 \%{ }^{21}$ while others show that it is only $5 \%{ }^{22,23}$ Although parents do not remember quite well the ages their children attain developmental milestones, they can identify what their children are able or not to do. ${ }^{24}$ This justifies the use of a questionnaire for parents which, additionally, is highly cost-effective in relation to the results it provides. ${ }^{25}$

Parents should be listened when they state their concern about the development of their children or when they fill in questionnaires about their development, ${ }^{25-28}$ although these perceptions are influenced by the social and economic level, language and the education level. ${ }^{28}$ Parents' opinions, expressed either orally during a visit to the office or written in a formal questionnaire, contribute to improving the identification of children who are at risk but, based on the results of the present study it does not replace the PRUNAPE, but it allows to better detect candidates to be tested. . $^{29-33}$

Child development and related problems will deserve much more attention in the future. The pediatrician and the rest of the healthcare personnel should receive more training and education in this field ${ }^{34}$ and the present questionnaire is an additional tool to the ones they already have at present. It is useful to better identify children who are candidates to be evaluated with the PRUNAPE at a low cost, thereby improving the cost-effective relationship in the healthcare process, supported by studies that prove the validity of the test in the confirmed developmental disorders, ${ }^{7}$ approach which is consistent with the international trends about the timely detection of developmental disorders. ${ }^{35}$

The PPV estimates the likelihood that a child has of failing the PRUNAPE if he or she did not pass the questionnaire. This enables that the referral to the test is made with the least possible false positive number. The pediatrician should know that the PPV, since it depends on the prevalence of developmental problems, in low prevalence settings (as it might happen in a consulting office of children who live in favorable social and economic conditions), the PPV of the questionnaire can be lower that the one in this study.

\section{CONCLUSIONS}

The questionnaire allows a more accurately identification of children who are candidates to the PRUNAPE. The lack of significant differences in the validity between the administration of the questionnaire by mothers or the healthcare personnel, or among mothers of a different education level, makes it a very operational tool in primary care. 


\section{Acknowledgments}

To Florencio Varela health promoters working at the following institutions: Sociedad de Fomento (SF) 17 de Diciembre in San Nicolás, SF of Barrio Parque, Cooperativa 20 de Diciembre of Villa Argentina, Centro de IntegraciónComunitaria Pico de Oro, SF of Villa Argentina.

To the pediatricians and psychologists who participated in this study: María José Coronel, Mariel Backman, Aldana Caro, Eliana Castellanelli, Constanza Cinat, Liliana Díaz, Mercedes Di Noto Roqué, Carolina Fabrizi, Clarisa Gómez, Patricia Isabel Hidalgo, Paola Leyes, Marina Elda López, Paula Lotes, Vanina Paola Romano and Romina Rosbelke. To pediatricians working at Hospital Ricardo Gutiérrez: Paola Czerniuk and María Belén Fernández.

To DGSA personnel: Graciela Blatt, B.S., María Cecilia Pascucci, M.D., Alicia Masautis, M.D., Oscar Fariña, M.D., secretaries Andrea Robles, Micaela Redlich, EsefaníaLandi, Florencia Andechaga. To Florencio Varela healthauthorities: Alejandro Mario Bagato, M.D., Héctor Miret, M.D., Gabriel Bejarano, B.S., and Juan Vieyra.

To Cristina Galoppo, M.D. and Ángela Gentile, M.D. of Hospital Ricardo Gutiérrez, and to Lorena Cordi, M.D., of Hospital P. de Elizalde.

To Acumar Communication Department: Galván, B.S., Beatriz Gómez Cevallos and FacundoBosco. To the IT Department: Esteban Neme, Eng., Alejandro Gómez Auad and Ariel Tassero.To DGSA secretaries.

\section{REFERENCES}

1. Lejarraga H, Kelmansky D, Pascucci MC, Salamanco G. Prueba Nacional de Pesquisa. PRUNAPE. Fundación Hospital Garrahan. 2004.

2. Pascucci MC, Lejarraga H, Kelmansky D, Alvarz M, et al. Validación de la Prueba Nacional de Pesquisa PRUNAPE. Arch Argent Pediatr2002;100(5):374-85.

3. Boggiano E, Breitman F, Andrade M. Sociedad Argentina de Pediatría. Comité de Pediatría Ambulatoria. Manual de supervisión de la Salud para niñas, niños y adolescentes. La detección oportuna de problemas de desarrollo. La prueba nacionaldePesquisaPRUNAPE.BuenosAires:SAP.Fundasap; 2010. Págs. 447-50.

4. Robbins LC. The accuracy of parental recall of aspects of child rearing practices. J AbnormPsychol 1963;66:261.

5. GlascoeFP.Evidence-based approach to developmental and behavioural surveillance using parents's concerns. Child Care Health Dev2000;26(2):137-49.

6. MinisteriodeSalud.SubsecretaríadeProgramasdePrevención yProtección de la Salud. Evaluación del Sistema de Vigilancia Epidemiológica. Buenos Aires, Argentina. Metodología para la construcción de un cuestionario para el sistema de vigilancia. Cap. 3: Pág. 18. 2003.

7. Lejarraga H, Menéndez A, Menzano E, Fattore MJ, et al. PRUNAPE: Pesquisa de trastornos de desarrollo en el primer nivel de atención. Arch ArgPediatr 2008;106(2):119-25.

8. Abusamra V, Ferreres A, Raiter A, De Beni R, et al. Test. Leer para Comprender TLC. Evaluación de la comprensión de textos. Buenos Aires: Paidós; 2010

9. Pascucci MC. La validación de tests de pesquisa. En: Lejarraga H. Desarrollo del niño en contexto. Buenos Aires: Paidós; 2006.

10. FrankemburgWK,vanDoorninckWJ,LiddellTN,DickNP. The Denver Prescreening Developmental Questionnaire (PDQ). Pediatrics 1976;57:744-53.

11. Frankemburg WK, Fandal AW, Thornton SM. Revision of Denver Pre-screening Developmental Questionnaire. J Pediatr1987;110(1):653-7.

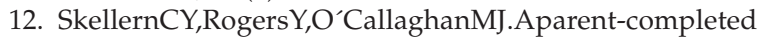
developmental questionnaire: Follow up of ex-premature infants. J Pediatr Child Health 2001;37(2):125-9.

13. Pool, JL. Parent-completed developmental screening for preschool children: A study of concurrent validity and reliability. Accessed on: July 5, 2013. Available at:

14. Chen IC, Kin CH. How effectively do parents discern their children 's cognitive deficits at preschool age? J Chin Med Assoc 2007;70(10):445-50.

15. Coghlan D, Kling JS. Parents evaluation of developmental status in the Australian day - care setting: developmental concerns of parents and careers. J Paediatr Child Health 2003;39(1):49-54.

16. Pulsifer MB, Hoon AH, Palmer FB, Gopalaw R, et al. Maternal estimates of developmental age in preschool children. J Pediatr1994;125(1):S18-24.

17. Malhi P, Kashyap S. Maternal estimates of mental age in developmentalassessment.IndianJPediatr2005;72(11):931-4.

18. Novick J. Ascertaining deviant behaviour in children. J Consul ClinPsychol1966;30:2-30.

19. Harris SR. Parents' and caregivers' perceptions oftheir children's development. Dev Med Child Neuroly1994;36(10):918-23.

20. Limbos MM, Joyce DP. Comparison of the ASQ and PEDS reeningfordevelopmentaldelayinchildrenpresenting for primary care. J DevBehavPediatr2011;32(7):499-511.

21. Saleh A. A brief screening questionnaire for infant sleep problems: validation findings for the internet sample. Pediatrics 2003;113:570-5.

22. Allen CW, Silone N, Williams K, Hutchins P. Validity of the social communication questionnaire in assessing risk of autism in pre-school children with developmental problems. Arch Dev Disorders 2007;37:1273-8.

23. Cox JEN, Huntington, et al. Developmental screening and parents written comments: an added dimension to the parents's evaluation of developmental status questionnaire. Pediatrics 2010;126(Suppl 3):170-6.

24. Glascoe FP. It is not what it seems. The relationship between parent 's concerns and children with global delays. ClinPediatr(Phila) 1994;33:292-6.

25. Glascoe FP, Foster EM. An economic analysis of developmental detection methods. Pediatrics 1997;99(6): 830-7.

26. Kiing JS, Low PS, Chan YH, Neihart M. Interpreting parents concerns about their children's development with the parents evaluation of developmental status: culture matters. J DevBehavPediatr2012;33(2):179-83.

27. GlascoeFP,AlthemeierWA,MacLeanWE.The importance of parents' concerns about their child's development. Am J Dis Child 1989;143(8):955-8.

28. McCune YD, Richardson MM, et al. Psychosocial health issues in pediatric practices: parents' knowledge and concerns. Pediatrics 1984;74(2):183-90.

29. GlascoeFP.Parents' concernsaboutchildren's development: prescreening technique or screening tests? Pediatrics 1997;99(4):522-8.

30. Glascoe FP, Dworkin PH. The role of parents in thedetection 
of developmental and behavioral problems. Pediatrics 1995;95(6):829-36.

31. Glascoe FP. Can clinical judgment detect children with speech-language problems? Pediatrics 1991;87(3):317-22.

32. Glascoe FP. Parents' evaluation of developmental status: how well do parents' concerns identify children with behavioral and emotional problems? ClinPediatr(Phila) 2003;42(2):133-8.

33. Meier JH. Screening, assessment, and intervention for young children at developmental risk. En: Yjossem TD, ed. Intervention Strategies for high risk infants and young children. Baltimore: University Park Press; USA, 1976.

34. Glascoe FP, Dworkin PH. Obstacles to effective developmental surveillance: errors in clinical reasoning. J Dev Behav Pediatr 1993;14(5):344-9.

35. Institute of Medicine. Neurological, psychiatric and developmental disorders. Meeting the challenge in the developing world. National Academic Press. Washington DC. Disponible:http//nap.edu/catalog/10111.html. [Acceso: January 2013.] 


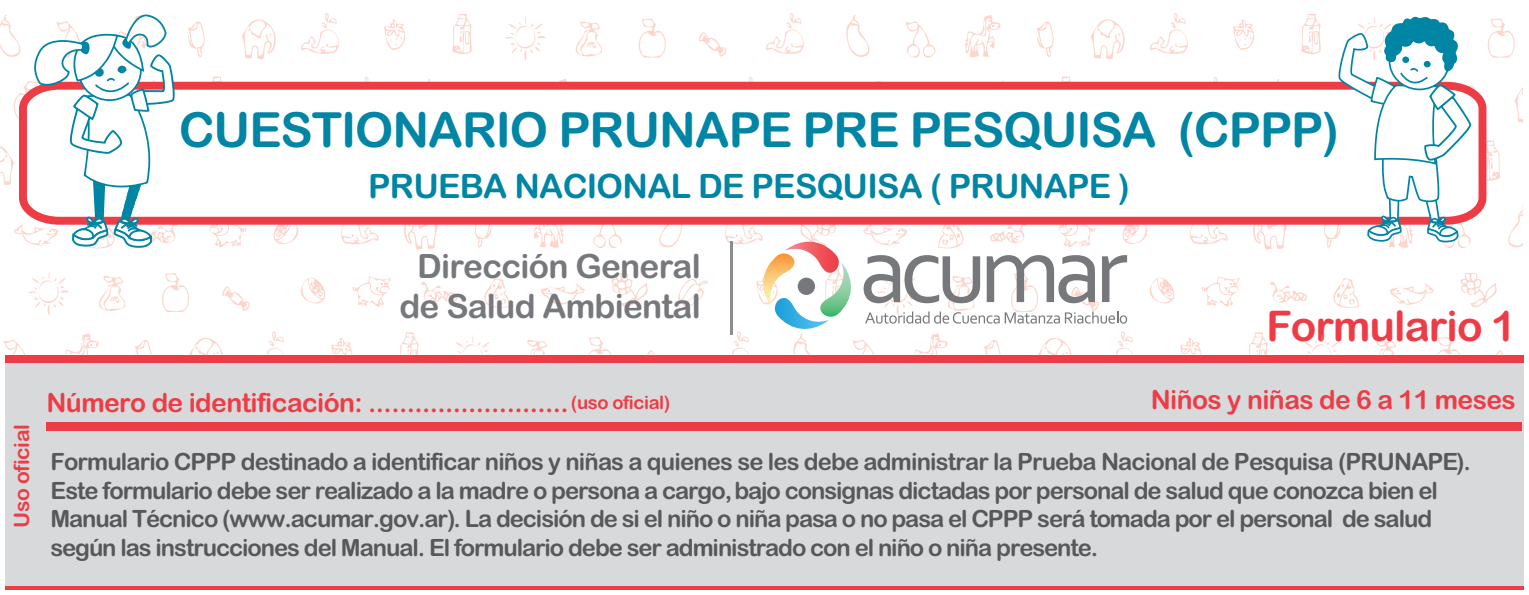

Fecha de hoy: .........................

\section{Datos del niño o niña}

Nombre:

Apellido: .

No Documento:

Fecha de nacimiento (día / mes / año):

............

Edad:

Peso al nacer:

(Kg)

Datos de la madre o persona a cargo

Nombre :

Apellido:

$N^{\circ}$ Documento:

Dirección:

Localidad:

Teléfono:

Marque con una $X$ el nivel educativo alcanzado: Primario incompleto

Secundario incompleto

Primario completo

Secundario completo

Terciario/Universitario

Este formulario tiene preguntas sobre las cosas que hacen los niños y las niñas. Queremos conocer cuáles ya puede hacer su niño o niña y cuáles todavía no. Lea cada pregunta y marque con una X lo que corresponda. Si tiene dudas, marque NO SÉ. niño o niña acostado boca arriba, ¿puede girar solo y ponerse de costado sin ayuda?
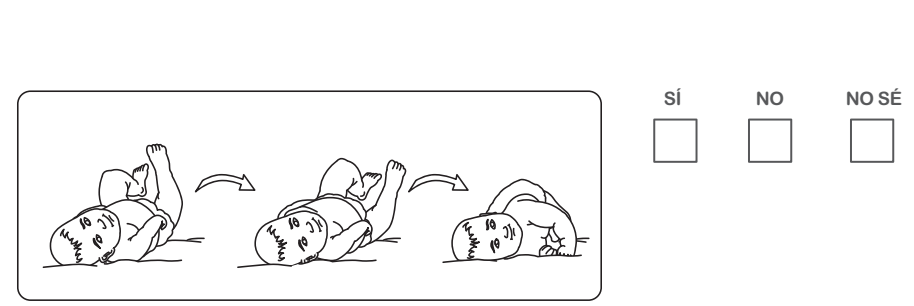

2 - Cuando usted llama al niño o niña, ¿la mira?

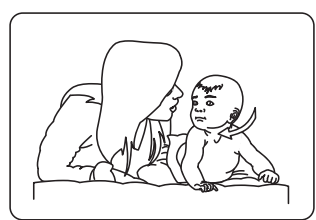

sí

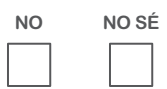

(39)

3 - Cuando usted sienta al niño o niña en el suelo, ¿puede sostenerse CON las manos apoyadas $\sin$ ayuda?

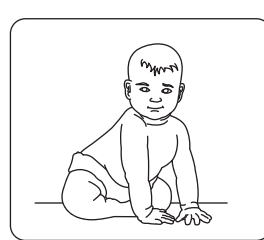

Si NO NO SÉ

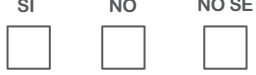

(62) 


\begin{tabular}{l}
4 - Cuando usted pone al ni \\
\hline 5 - ¿El niño o niña puede \\
agarrar un objeto pequeño \\
(como un pedacito de pan) \\
con la mano?
\end{tabular}
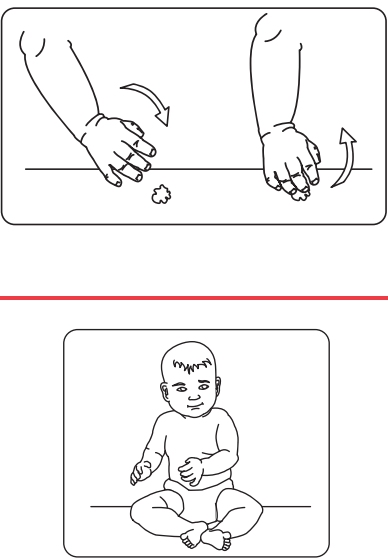

\section{objeto o juguete en la mano,}

7 - Cuando el niño o niña tiene un

¿se resiste a que se lo quiten?
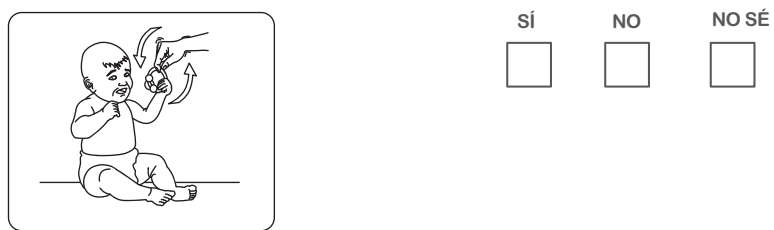

(4)

\section{8 - ¿El niño o niña juega a esconderse si usted le tapa la cara con un trapo o una tela?}

\section{0 - Cuando el niño o niña está sentado en el suelo, ¿puede agarrar un objeto o juguete cercano?}

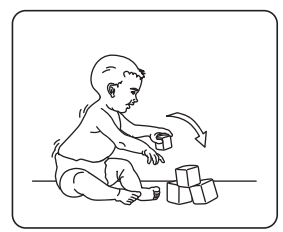

11 - ¿El niño o niña dice "ma-ma-ma" o "pa-pa-pa”?

12 - ¿El niño o niña entiende cuando usted le dice NO?
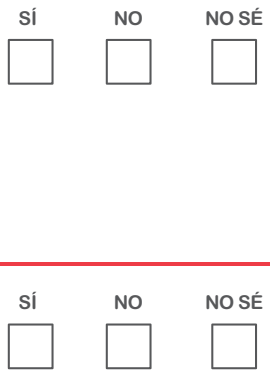

(64)

(42)

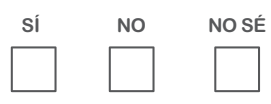

(40) 

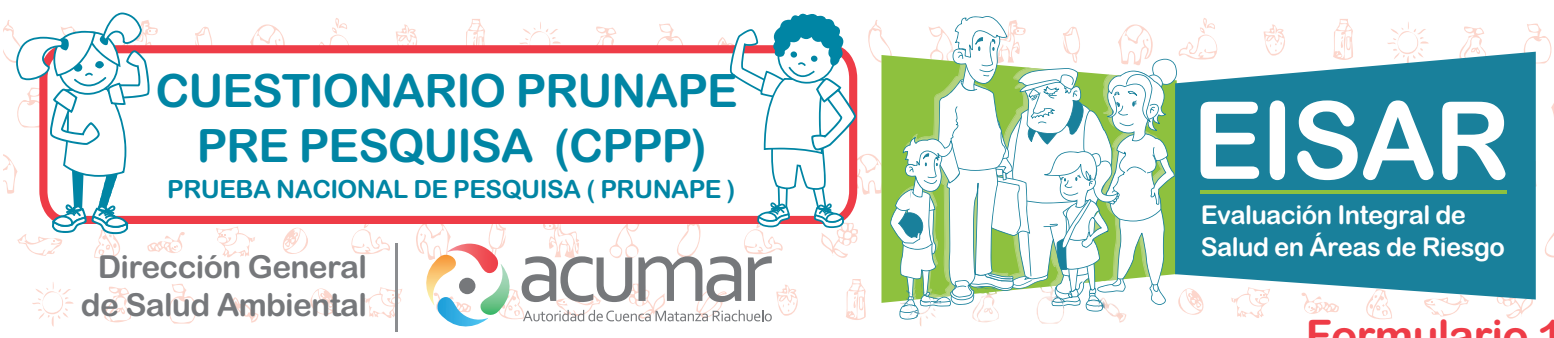

\section{Formulario 1}

13 - Cuando usted cubre un objeto ( juguete u otra cosa...) con un pañuelo o tela, ¿el niño o niña levanta el pañuelo o la tela para encontrarlo?

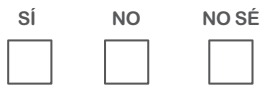

Uso oficial Pauta PRUNAPE N
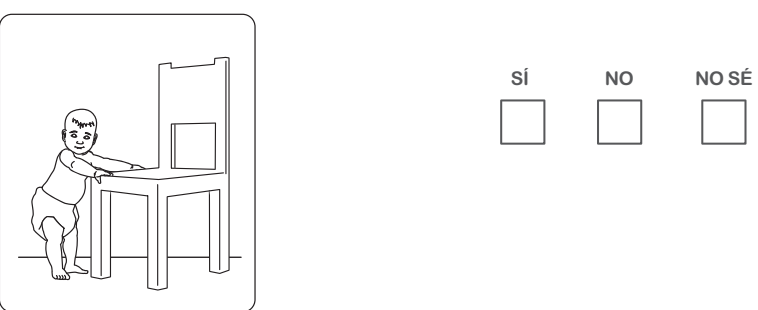

(66)

sosteniéndose de una silla, mesa o algún otro mueble?
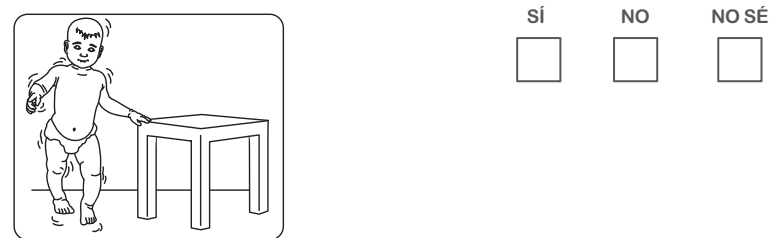

(6)

15 - ¿El niño o niña camina algunos pasos agarrándose de algún mueble?

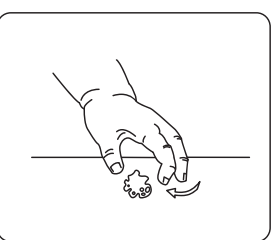




\section{Uso oficial: Resultados del CPPP - para ser completado por personal de salud.}

1- La edad del niño o niña es

meses.......

días

2- Las preguntas a considerar aquí son aquellas cuyo percentil 90 es menor que la edad del niño o niña; márquela con una $X$ y luego tilde "CUMPLE" o "NO CUMPLE".

\begin{tabular}{|c|c|c|c|c|}
\hline Pregunta $\mathrm{N}^{\circ}$ & $\begin{array}{l}\text { Preguntas a } \\
\text { considerar }\end{array}$ & Percentil 90 & Cumple & $\begin{array}{c}\text { No Cumple } \\
\text { (no sabe, no colabora) }\end{array}$ \\
\hline $1-$ & $\square$ & $5 \mathrm{~m} 23 d$ & $\square$ & $\square$ \\
\hline $2-$ & $\square$ & $5 \mathrm{~m} \mathrm{26d}$ & $\square$ & $\square$ \\
\hline 3- & $\square$ & $5 \mathrm{~m} \mathrm{26d}$ & $\square$ & $\square$ \\
\hline $4-$ & $\square$ & $6 m$ & $\square$ & $\square$ \\
\hline $5-$ & $\square$ & $6 \mathrm{~m} 29 \mathrm{~d}$ & $\square$ & $\square$ \\
\hline $6-$ & $\square$ & $7 \mathrm{~m} 24 \mathrm{~d}$ & $\square$ & $\square$ \\
\hline 7- & $\square$ & $8 \mathrm{~m} 5 \mathrm{~d}$ & $\square$ & $\square$ \\
\hline 8- & $\square$ & $8 \mathrm{~m} 5 \mathrm{~d}$ & $\square$ & $\square$ \\
\hline 9- & $\square$ & $8 \mathrm{~m} \mathrm{12d}$ & $\square$ & $\square$ \\
\hline $10-$ & $\square$ & $9 m$ & $\square$ & $\square$ \\
\hline $11-$ & $\square$ & $9 \mathrm{~m} 18 \mathrm{~d}$ & $\square$ & $\square$ \\
\hline $12-$ & $\square$ & $9 \mathrm{~m} 25 \mathrm{~d}$ & $\square$ & $\square$ \\
\hline 13- & $\square$ & $10 \mathrm{~m} \mathrm{24d}$ & $\square$ & $\square$ \\
\hline $14-$ & $\square$ & $11 \mathrm{~m} 12 \mathrm{~d}$ & $\square$ & $\square$ \\
\hline $15-$ & $\square$ & $11 \mathrm{~m} \mathrm{23d}$ & $\square$ & $\square$ \\
\hline $16-$ & $\square$ & $11 \mathrm{~m} \mathrm{26d}$ & $\square$ & $\square$ \\
\hline
\end{tabular}

El niño o niña no pasa el CPPP si la respuesta es NO CUMPLE en dos de las preguntas consideradas.

3-RESULTADO FINAL: PASA $\square$ NOPASA $\square$ (administrar PRUNAPE)

Nombre y apellido del agente de salud interviniente:

Lugar: ...... 


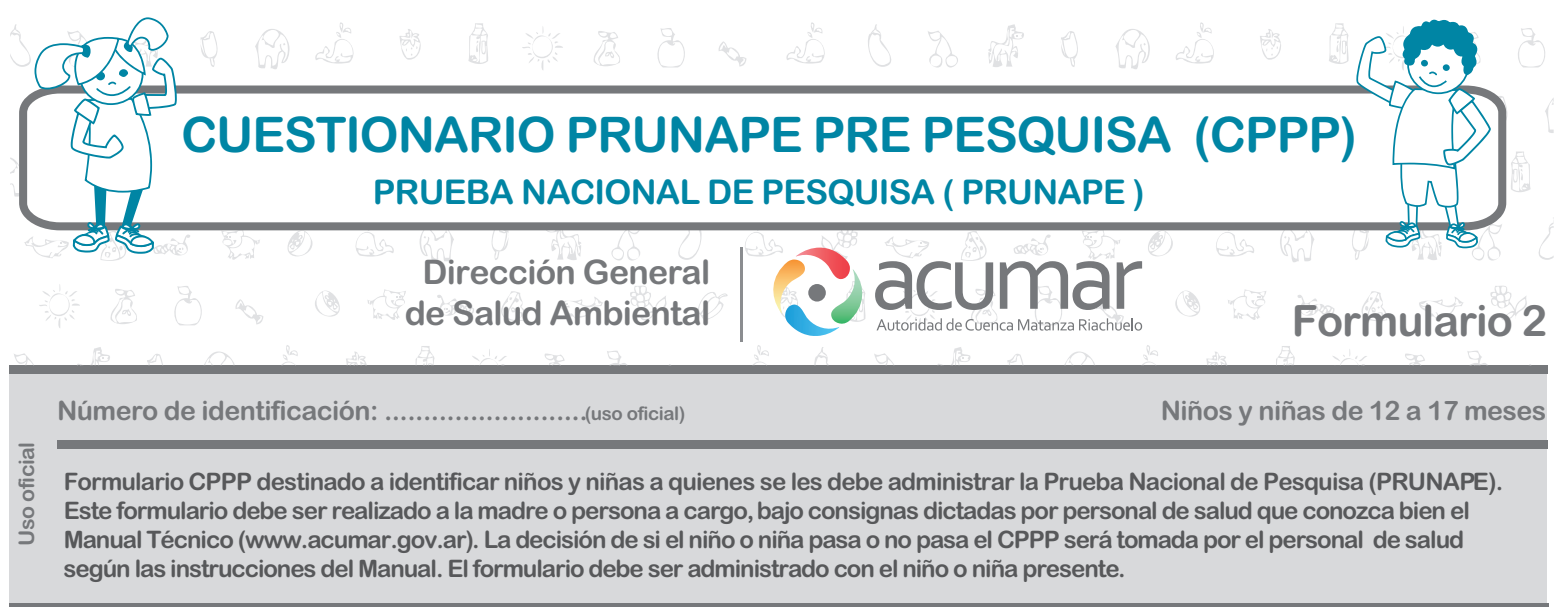

Fecha de hoy: ..........................

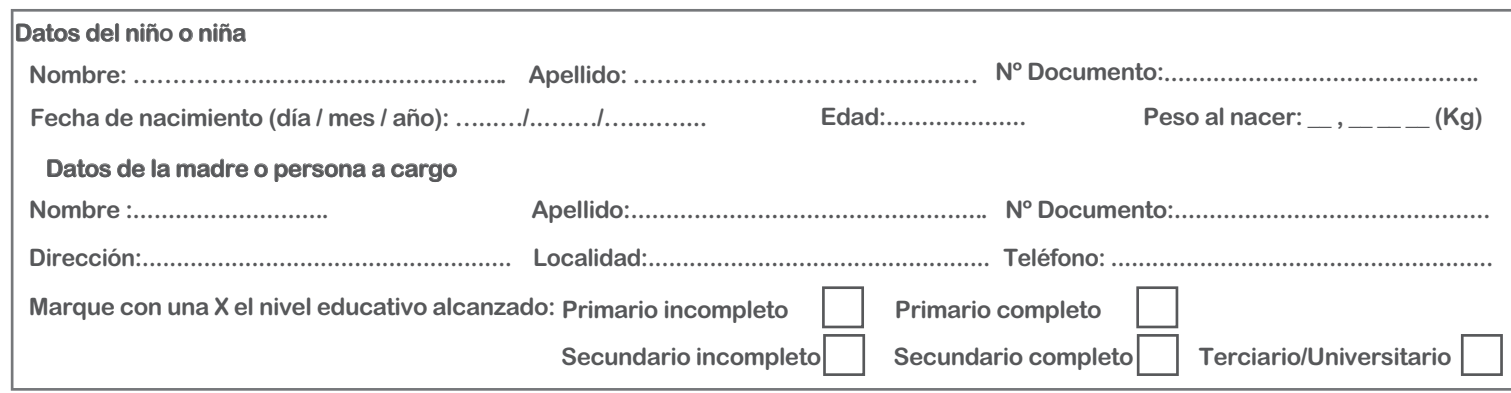

Este formulario tiene preguntas sobre las cosas que hacen los niños y las niñas. Queremos conocer cuáles ya puede hacer su niño o niña y cuáles todavía no. Lea cada pregunta y marque con una X lo que corresponda. Si tiene dudas, marque NO SÉ.

1 - Cuando el niño o niña está sentado en el suelo, ¿puede agarrar un objeto o juguete cercano?

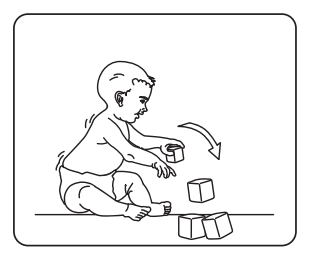

Uso oficial Pauta PRUNAPE N

(10)

2 - ¿El niño o niña dice "ma-ma-ma” o "pa-pa-pa”?

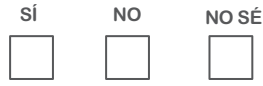

(42)

3 - ¿El niño o niña entiende cuando usted le dice NO?

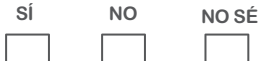

(40)

4 - Cuando usted cubre un objeto (juguete, otra cosa...) con un papel o una tela, ¿el niño o niña levanta el papel o la tela para encontrarlo?

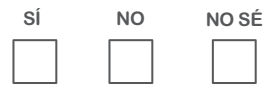

(6) 
5 - ¿El niño o niña puede pararse sosteniéndose de una silla, mesa o algún otro mueble?

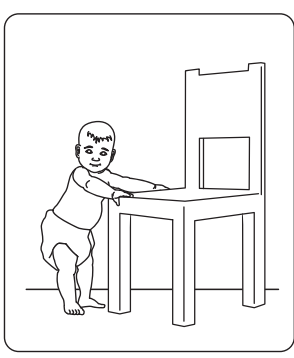

Si NO NO SÉ
$\square$

(66)

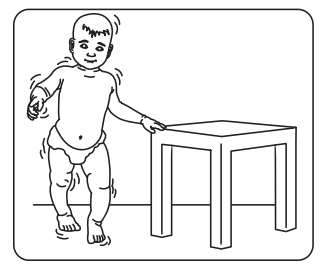

Si NO NO SÉ

(67) agarrándose de algún mueble?
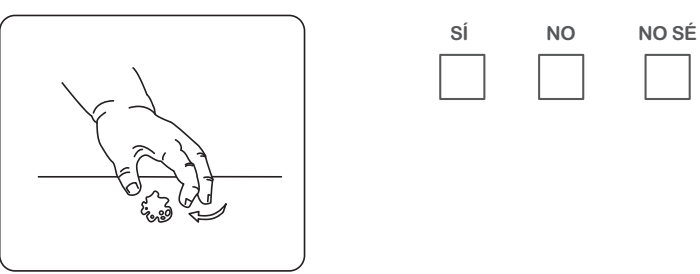

(25) dedo pulgar y su dedo índice?
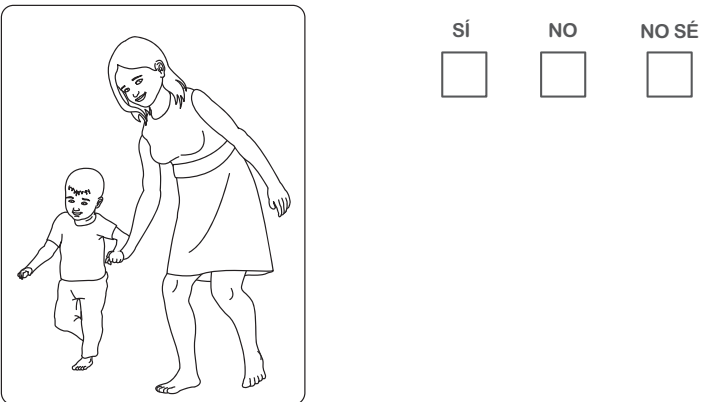

(68) alguien?

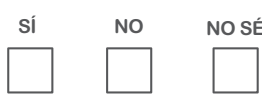

(69)
9 - ¿El niño o niña camina solo?

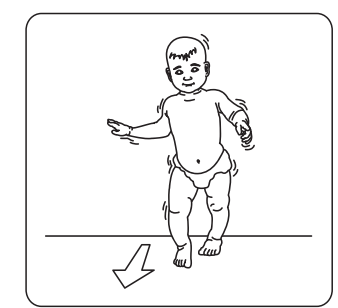




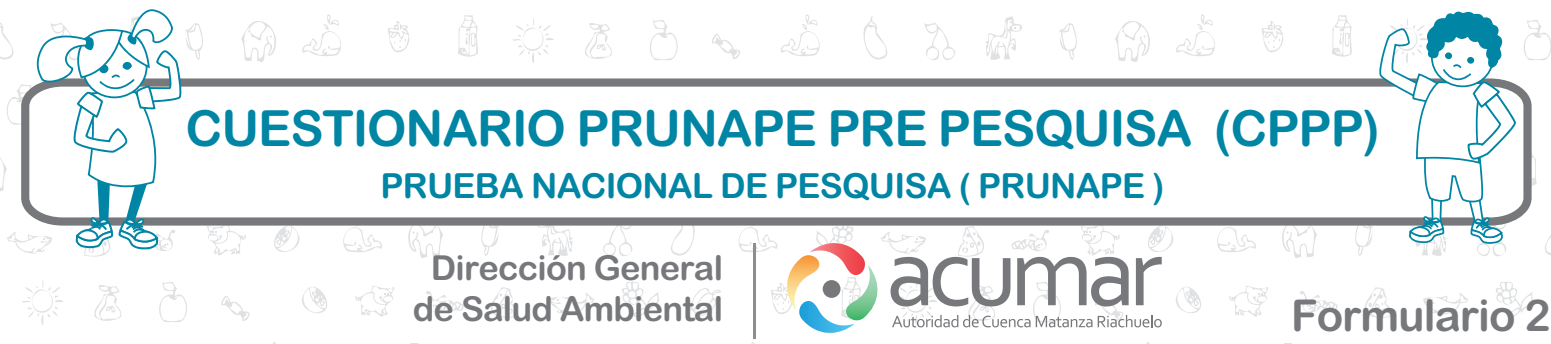

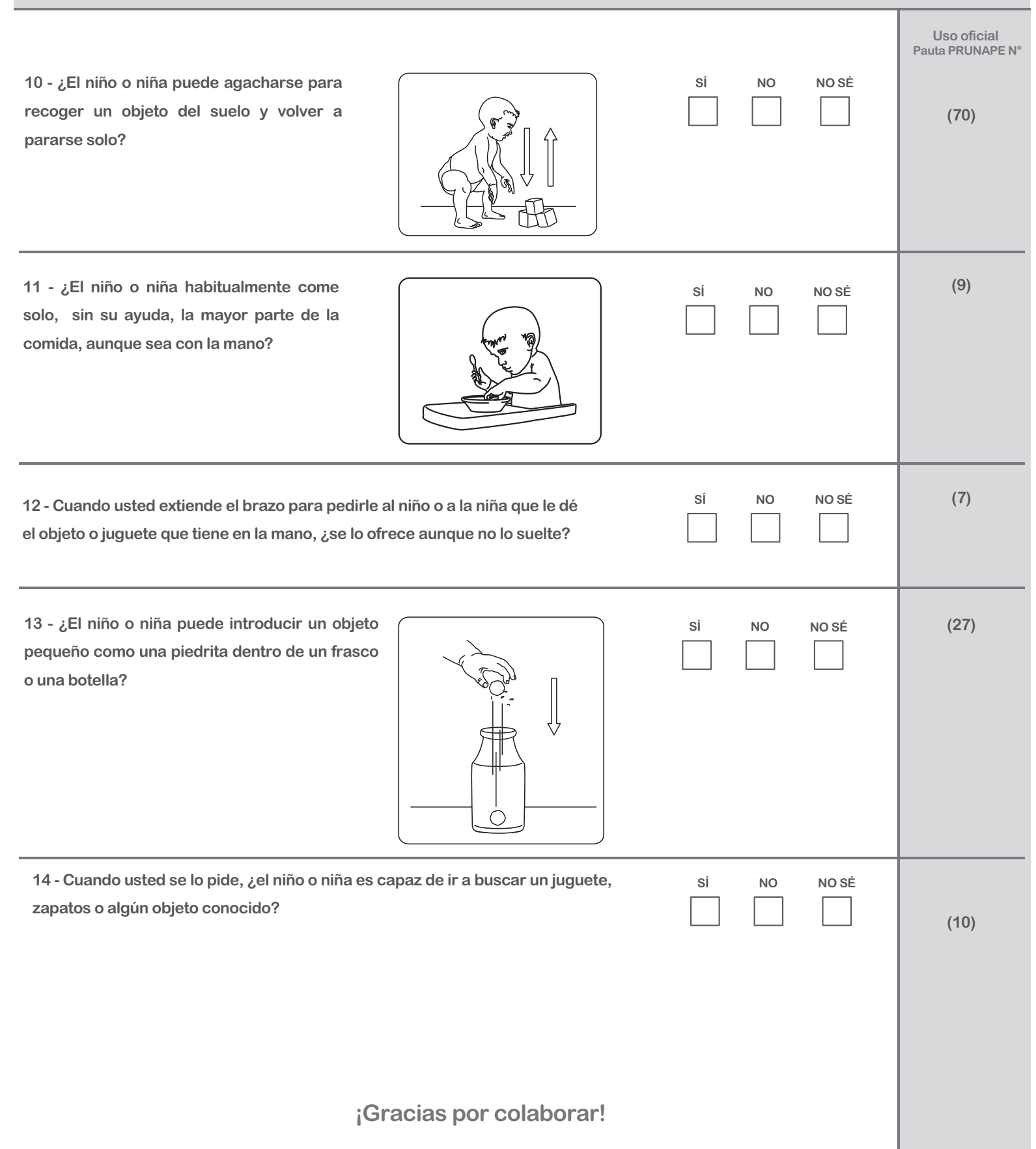




\section{Uso oficial: Resultados del CPPP - para ser completado por personal de salud.}

1- La edad del niño o niña es meses. días

2- Las preguntas a considerar aquí son aquellas cuyo percentil 75 es menor que la edad del niño o niña; márquela con una X y luego tilde "CUMPLE" o "NO CUMPLE".

\begin{tabular}{|c|c|c|c|c|}
\hline Pregunta $\mathrm{N}^{\circ}$ & $\begin{array}{l}\text { Preguntas a } \\
\text { considerar }\end{array}$ & Percentil 75 & Cumple & $\begin{array}{c}\text { No Cumple, } \\
\text { (no sabe, no colabora }\end{array}$ \\
\hline $1-$ & & $7 \mathrm{~m} \mathrm{13d}$ & & \\
\hline $2-$ & & $8 \mathrm{~m} 8 d$ & & \\
\hline $3-$ & & $7 \mathrm{~m} 2 \mathrm{~d}$ & & \\
\hline 4- & & $9 \mathrm{~m} 4 \mathrm{~d}$ & & \\
\hline $5-$ & & $10 \mathrm{~m} 20 \mathrm{~d}$ & & \\
\hline $6-$ & & $10 \mathrm{~m} 17 \mathrm{~d}$ & & \\
\hline $7-$ & & $10 \mathrm{~m} 13 \mathrm{~d}$ & & \\
\hline 8- & & $11 \mathrm{~m} 8 \mathrm{~d}$ & 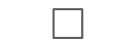 & \\
\hline 9- & & $13 \mathrm{~m} 17 \mathrm{~d}$ & & \\
\hline $10-$ & & $13 m 13 d$ & & \\
\hline $11-$ & & $16 \mathrm{~m} 2 \mathrm{~d}$ & & 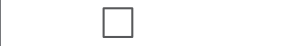 \\
\hline $12-$ & & $12 \mathrm{~m} 29 \mathrm{~d}$ & 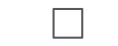 & - \\
\hline $13-$ & & $14 \mathrm{~m} 16 \mathrm{~d}$ & & 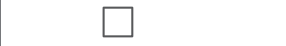 \\
\hline 14- & $\square$ & $15 \mathrm{~m}$ & $\square$ & $\square$ \\
\hline
\end{tabular}

EI niño no pasa el CPPP si la respuesta es NO CUMPLE en dos de las preguntas consideradas.

3- RESULTADO FINAL: PASA $\square$ NO PASA $\square$ (administrar PRUNAPE)

Nombre y apellido del agente de salud interviniente:

Lugar: . 


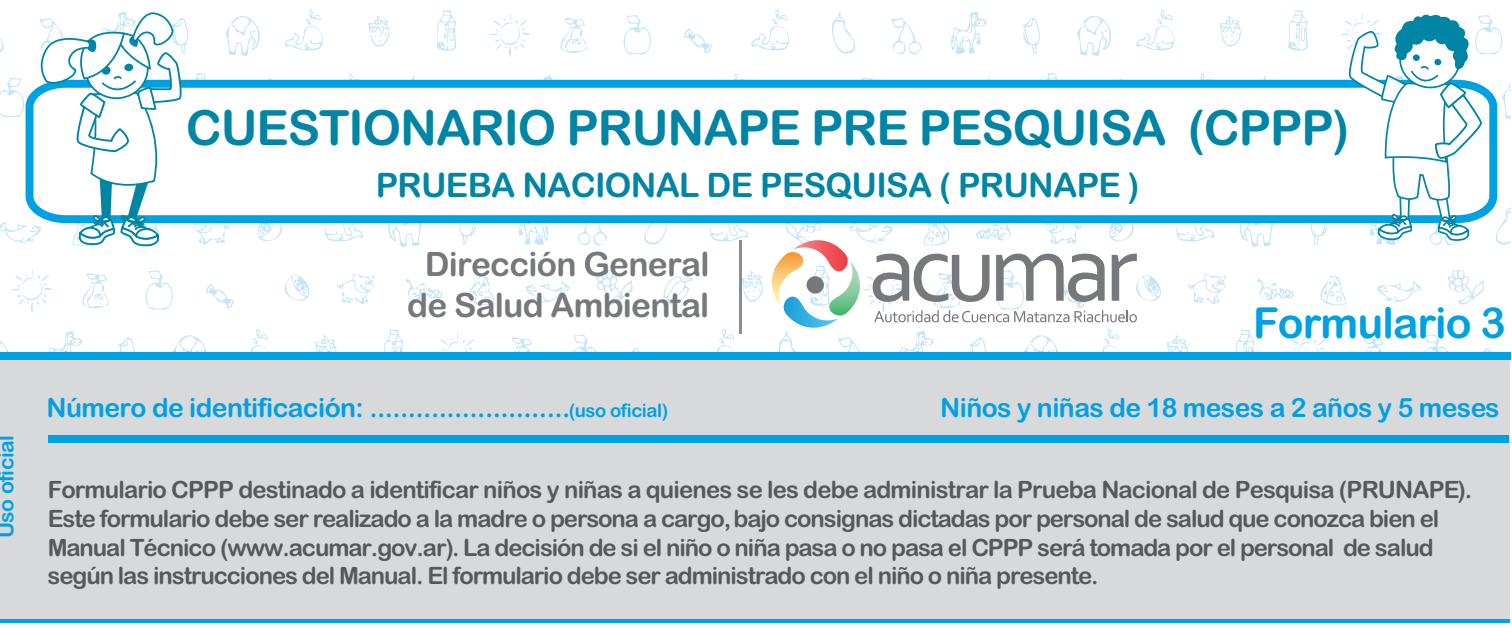

Fecha de hoy: ..........................

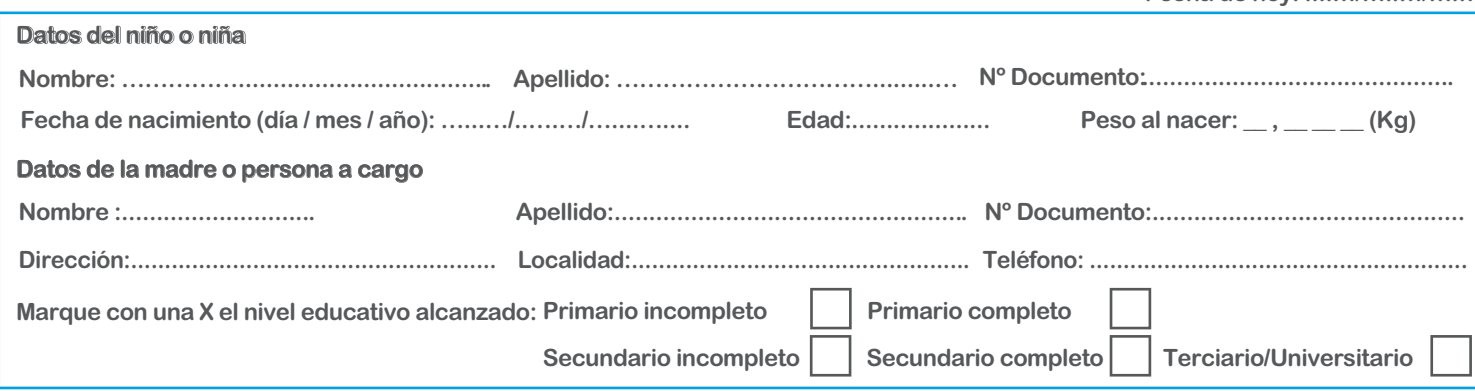

Este formulario tiene preguntas sobre las cosas que hacen los niños y las niñas. Queremos conocer cuáles ya puede hacer su niño o niña y cuáles todavía no. Lea cada pregunta y marque con una X lo que corresponda. Si tiene dudas, marque NO SÉ.

1 - ¿El niño o niña habitualmente come solo o sin su ayuda la mayor parte de la comida, aunque sea con la mano?

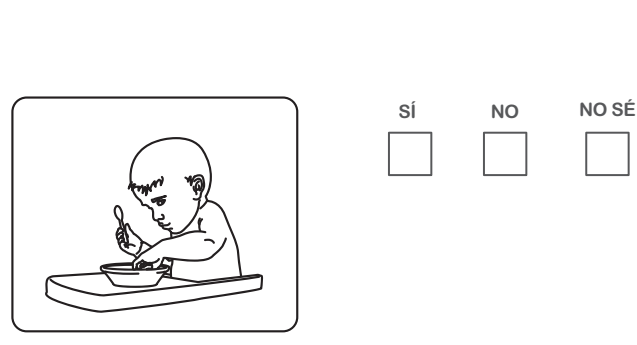

2 - ¿El niño o niña puede introducir un objeto pequeño como una piedrita dentro de un frasco o una botella?
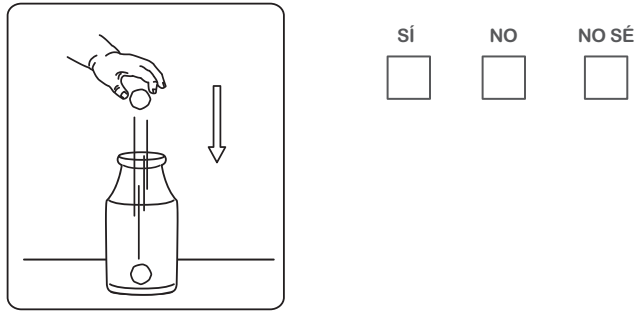

3 - Cuando usted extiende el brazo para pedirle al niño o a la niña que le dé el sí objeto o juguete que tiene en la mano, ¿se lo ofrece aunque no lo suelte?

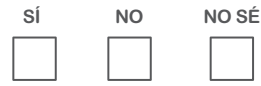


4 - Cuando usted se lo pide, ¿el niño o niña es capaz de ir a buscar un juguete, zapatos o algún objeto conocido?

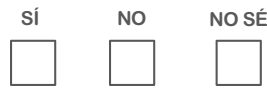

(10)

5 - ¿El niño o niña juega con muñecas haciendo como que les da de comer, los peina o los hace dormir? ¿O juega con autitos, haciendo que cargan nafta, estacionan o andan?
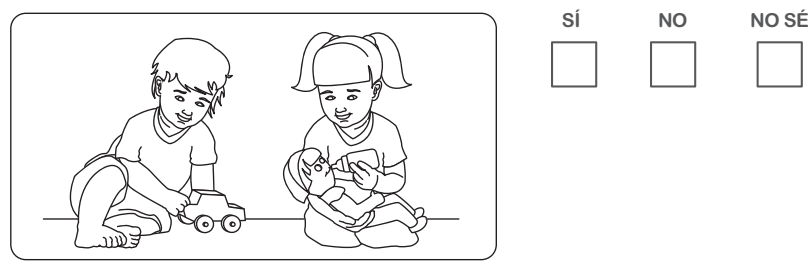

(8)

6 - ¿El niño o niña puede subirse a una silla sin ayuda?
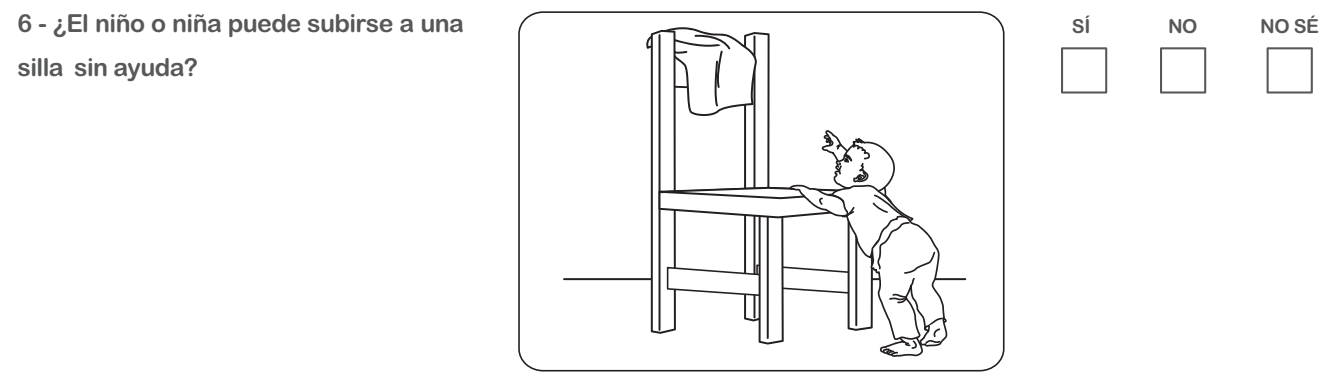

Uso oficial Pauta PRUNAPE ${ }^{\circ}$

7 - ¿El niño o niña puede hacer con un lápiz una raya o garabato en un papel?

8 - ¿El niño o niña copia a veces lo que usted está haciendo, como limpiar algo, sí NO NO SÉ pasar un trapo, barrer...?

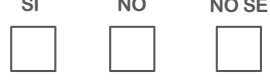

(12)

9 - ¿El niño o niña dice "mamá" a la mamá o "papá” al papá?

sí

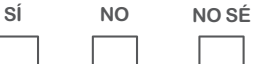

(43)

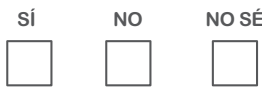

(71)

(44)

11 - ¿El niño o niña utiliza alguna palabra para pedir lo que quiere, por ejemplo “agua”, "leche”, “pan”, “galletita”, aunque no la pronuncie bien? 


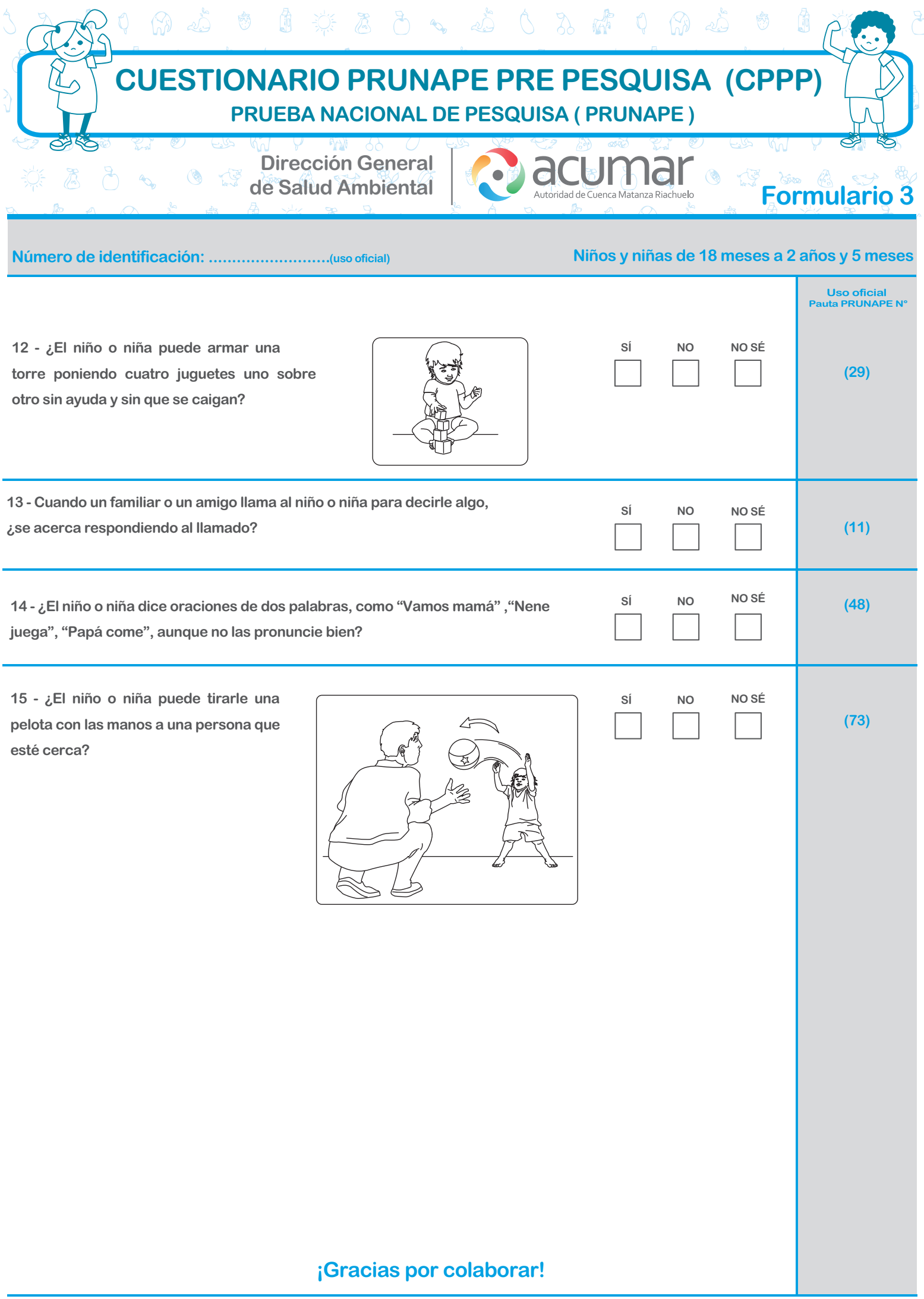




\section{Uso oficial: Resultados del CPPP - para ser completado por personal de salud.}

1- La edad del niño o niña es meses. días

2- Las preguntas a considerar aquí son aquellas cuyo percentil 75 es menor que la edad del niño o niña; márquela con una $X$ y luego tilde "CUMPLE" o "NO CUMPLE".

\begin{tabular}{|c|c|c|c|c|}
\hline Pregunta $N^{\circ}$ & $\begin{array}{l}\text { Preguntas a } \\
\text { considerar }\end{array}$ & Percentil 75 & Cumple & $\begin{array}{c}\text { No Cumple, } \\
\text { (no sabe, no colabora) }\end{array}$ \\
\hline $1-$ & 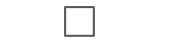 & $16 \mathrm{~m} 2 \mathrm{~d}$ & & \\
\hline $2-$ & L & $14 \mathrm{~m} 16 \mathrm{~d}$ & & \\
\hline 3- & & $12 \mathrm{~m} 29 d$ & & \\
\hline 4- & & $15 \mathrm{~m}$ & & \\
\hline $5-$ & 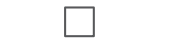 & $13 \mathrm{~m} 28 d$ & & \\
\hline 6- & & $16 \mathrm{~m} 6 \mathrm{~d}$ & & \\
\hline $7-$ & $\Gamma$ & $15 \mathrm{~m} 4 \mathrm{~d}$ & & \\
\hline 8- & L & $15 \mathrm{~m} \mathrm{14d}$ & & \\
\hline 9- & $\square$ & $16 \mathrm{~m} 10 \mathrm{~d}$ & & \\
\hline $10-$ & $\square$ & $15 \mathrm{~m} 11 \mathrm{~d}$ & & L \\
\hline $11-$ & 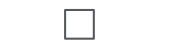 & $16 \mathrm{~m} 28 d$ & & \\
\hline $12-$ & $\square$ & $19 \mathrm{~m} 28 d$ & L & $\square$ \\
\hline $13-$ & $\square$ & $18 \mathrm{~m} 29 \mathrm{~d}$ & $\square$ & $\square$ \\
\hline 14- & $\square$ & $25 \mathrm{~m} 28 d$ & $\square$ & $\square$ \\
\hline 15- & $\square$ & $22 \mathrm{~m} 6 \mathrm{~d}$ & $\square$ & $\square$ \\
\hline
\end{tabular}

El niño o niña no pasa el CPPP si la respuesta es NO CUMPLE en dos de las preguntas consideradas.

3- RESULTADO FINAL: PASA $\square$ NO PASA $\square$ (administrar PRUNAPE)

Nombre y apellido del agente de salud interviniente:

Lugar: 


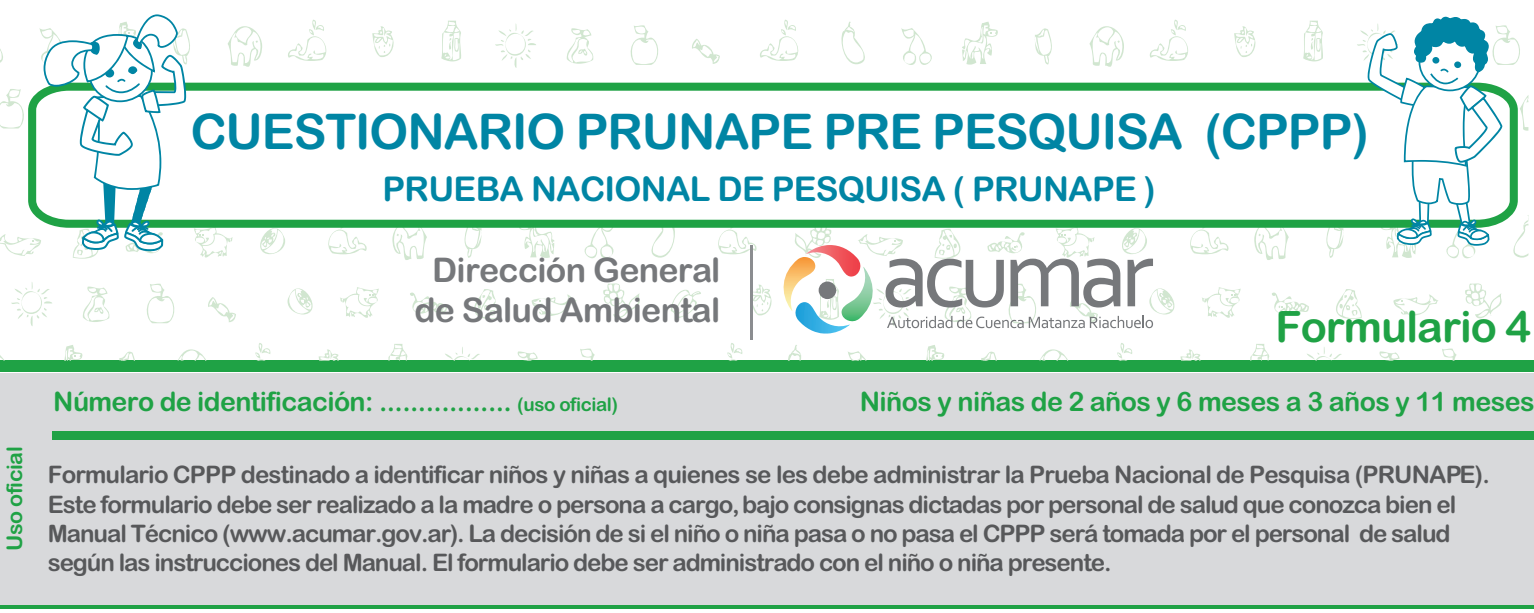

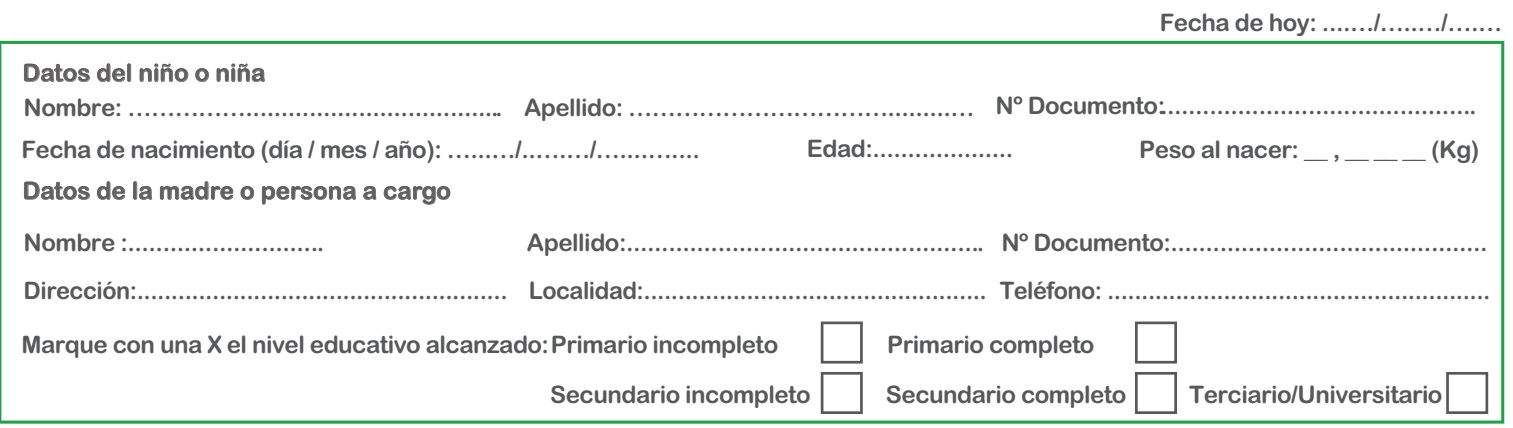

Este formulario tiene preguntas sobre las cosas que hacen los niños y las niñas. Queremos conocer cuáles ya puede hacer su niño o niña y cuáles todavía no. Lea cada pregunta y marque con una $X$ lo que corresponda. Si tiene dudas, marque NO SÉ.

1 - Cuando un familliar o amigo llama al niño o niña para decirle algo, ¿se

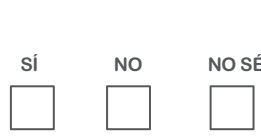

Uso oficial acerca respondiendo al llamado?

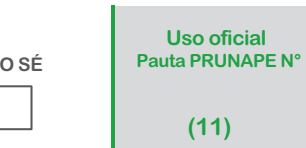

2 - ¿El niño o niña dice oraciones de dos palabras, como "Vamos mamá",

"Nene juega", "Papá come", aunque no las pronuncie bien?

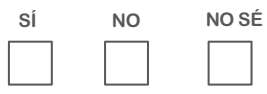

(48)

3 - ¿El niño o niña puede tirarle una
pelota con las manos a una
persona que esté cerca?
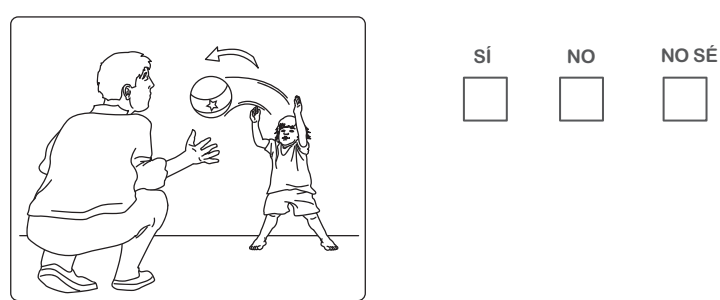

(73)

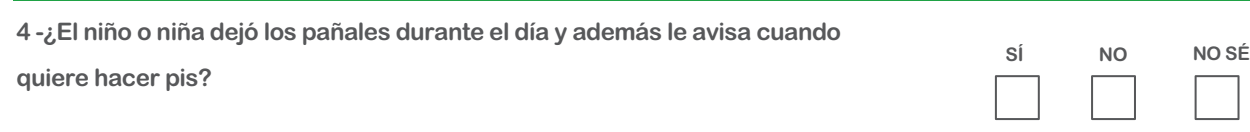

(15) 


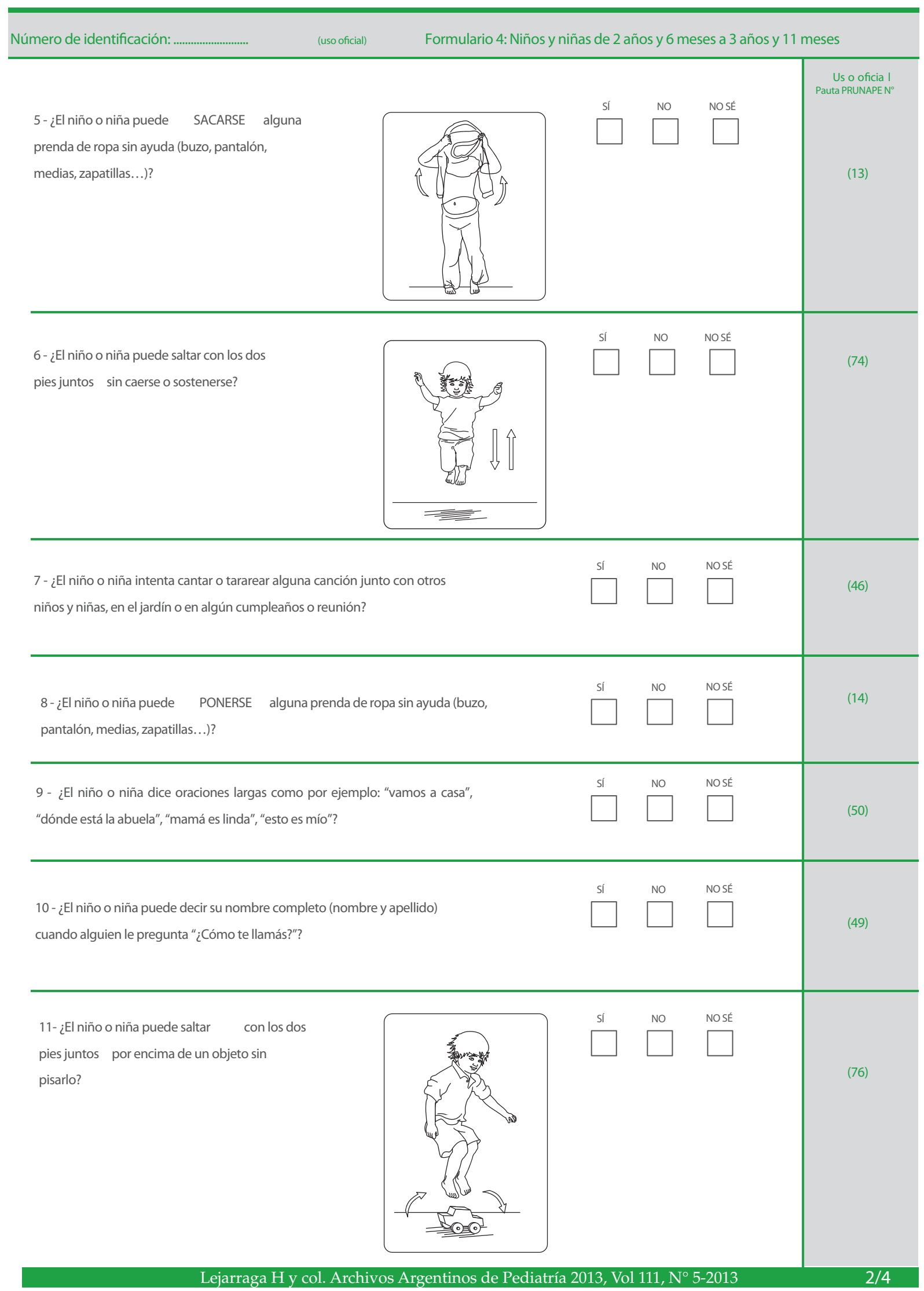




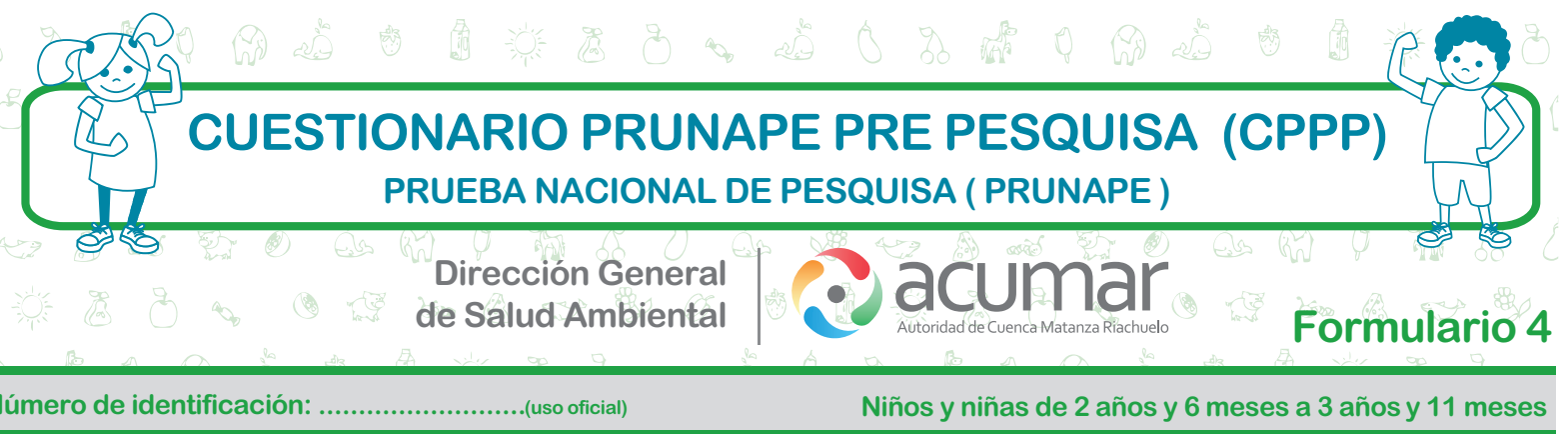

Para responder lo que sigue USTED tiene que pedirle al niño o niña que haga algunas pruebas. Si el niño o niña no las puede hacer, marque NO. Si el niño o niña no quiere hacerlas, marque NO COLABORA.

12 - Señale usted las figuras de este dibujo y pídale al niño o niña que las nombre preguntándole “¿Éste quién es?”. Si puede reconocer dos o más figuras marque sí.

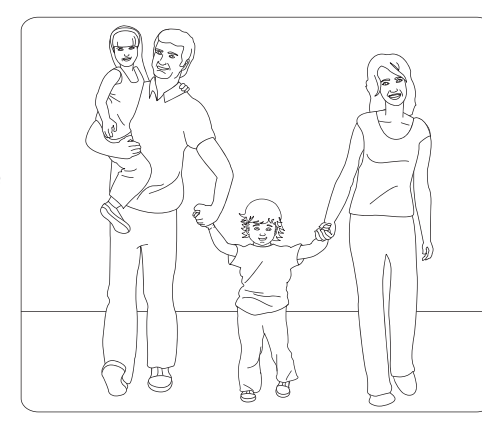

13 - Pídale al niño o niña que se pare en un solo pie sin apoyarse. Múestrele cómo debe hacerlo.

Dele dos o tres oportunidades y si puede hacerlo sin caerse, marque sí.

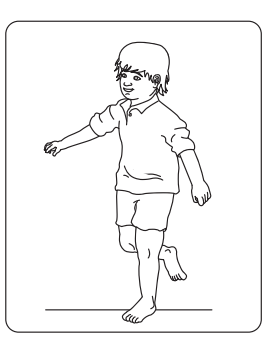

14 - Muéstrele un color al niño o niña y pídale que señale el que se le parece.

Si el niño o niña puede señalar correctamente dos o más, marque sí.

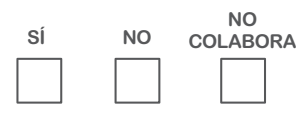

Uso oficial Pauta PRUNAPE N ${ }^{\circ}$

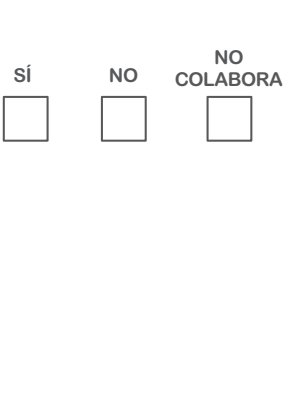

(47) Si NO NOLABORA

$\square \quad \square \quad(75)$
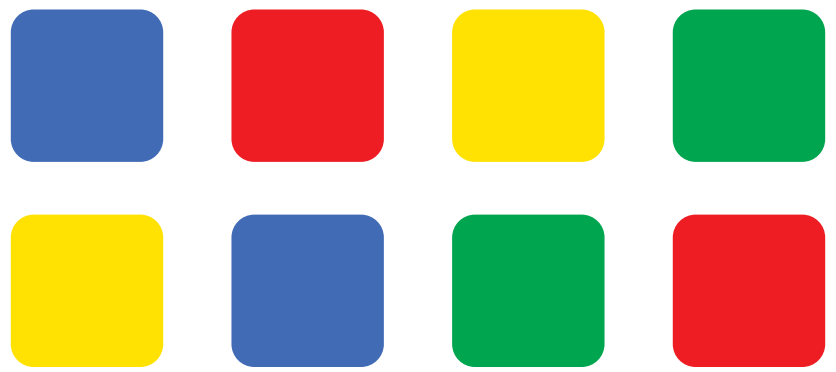

¡Gracias por colaborar! 


\section{Uso oficial: Resultados del CPPP - para ser completado por personal de salud.}

1- La edad del niño o niña es meses.. días

2- Las preguntas a considerar aquí son aquellas cuyo percentil 90 es menor que la edad del niño o niña; márquela con una $X$ y luego tilde "CUMPLE” o "NO CUMPLE".

\begin{tabular}{|c|c|c|c|c|}
\hline Pregunta $N^{\circ}$ & $\begin{array}{c}\text { Preguntas a } \\
\text { considerar }\end{array}$ & Percentil 90 & Cumple & $\begin{array}{c}\text { No Cumple, } \\
\text { (no sabe, no colabora) }\end{array}$ \\
\hline $1-$ & & $28 \mathrm{~m} 6 \mathrm{~d}$ & & \\
\hline 2- & & $28 \mathrm{~m} 28 \mathrm{~d}$ & & \\
\hline 3- & 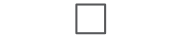 & $29 \mathrm{~m} 1 \mathrm{~d}$ & & \\
\hline 4- & & $32 \mathrm{~m} 16 \mathrm{~d}$ & & \\
\hline 5- & & $33 \mathrm{~m} 22 \mathrm{~d}$ & & \\
\hline $6-$ & & $33 \mathrm{~m} 29 d$ & & \\
\hline 7- & & $34 \mathrm{~m} 2 \mathrm{~d}$ & & \\
\hline 8- & & $36 \mathrm{~m} 4 \mathrm{~d}$ & & \\
\hline 9- & & $37 \mathrm{~m} 17 \mathrm{~d}$ & & \\
\hline $10-$ & & $43 \mathrm{~m} 10 \mathrm{~d}$ & & \\
\hline 11- & & $45 \mathrm{~m} 22 \mathrm{~d}$ & & \\
\hline $12-$ & $\square$ & $28 \mathrm{~m} 20 \mathrm{~d}$ & & 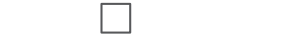 \\
\hline 13- & & $45 \mathrm{~m} 18 \mathrm{~d}$ & $\square$ & 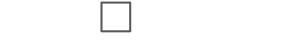 \\
\hline 14- & 7 & $45 \mathrm{~m} 18 d$ & & \\
\hline
\end{tabular}

El niño o niña no pasa el CPPP si la respuesta es NO CUMPLE en una de las preguntas consideradas.

3-RESULTADO FINAL: PASA $\square$ NO PASA $\square$ (administrar PRUNAPE)

Nombre y apellido del agente de salud interviniente: .

Lugar: 


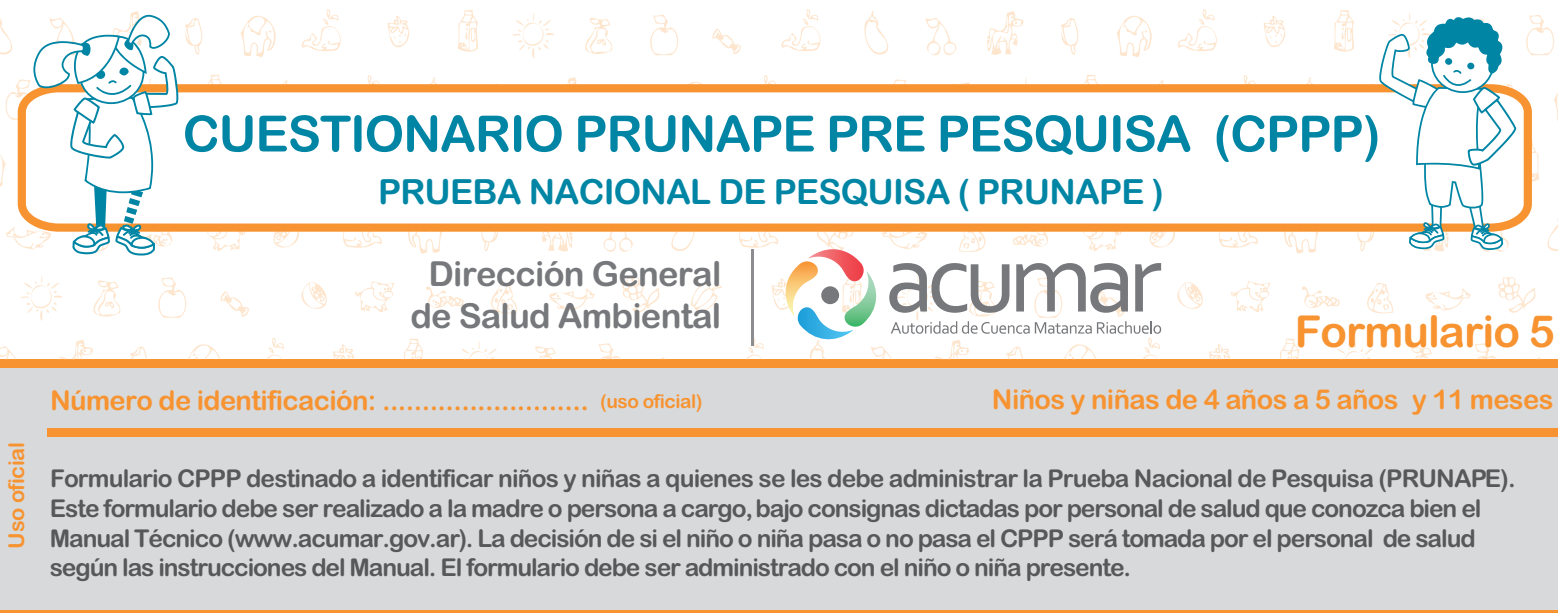

Fecha de hoy: ......................

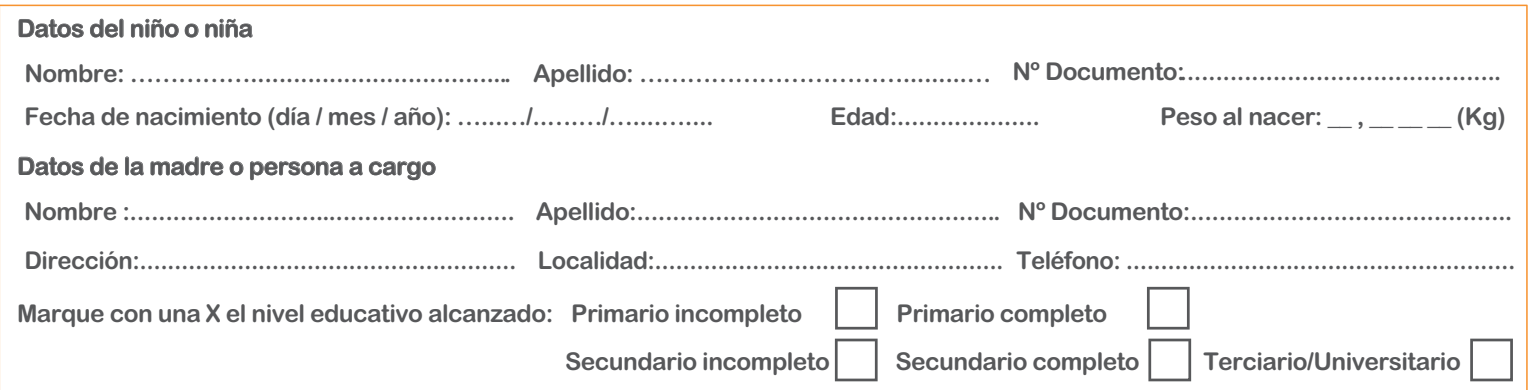

Este formulario tiene preguntas sobre las cosas que hacen los niños y las niñas. Queremos conocer cuáles ya puede hacer su niño o niña y cuáles todavía no. Lea cada pregunta y marque con una $X$ lo que corresponda. Si tiene dudas, marque NO SÉ.

1 - ¿El niño o niña puede saltar con los dos pies juntos por encima de un objeto sin pisarlo?

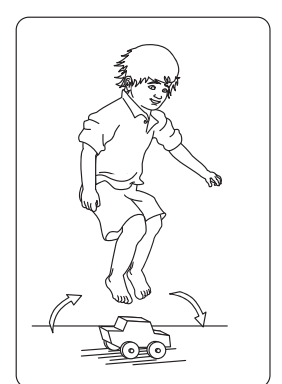

Uso oficial Pauta PRUNAPE N

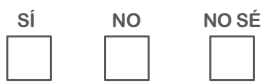

(76)

2 - ¿ El niño o niña puede cumplir dos indicaciones seguidas cuando usted se lo pide? Por ejemplo: "traé tus zapatillas y cerrá la puerta”, "dame el pan y llamá a la abuela" o "buscá tu mochila y sentate".

sí 
3 - Muéstrele un color al niño o niña y pídale que señale el que se le parece. Si el niño o niña puede señalar correctamente dos o más, marque sí.

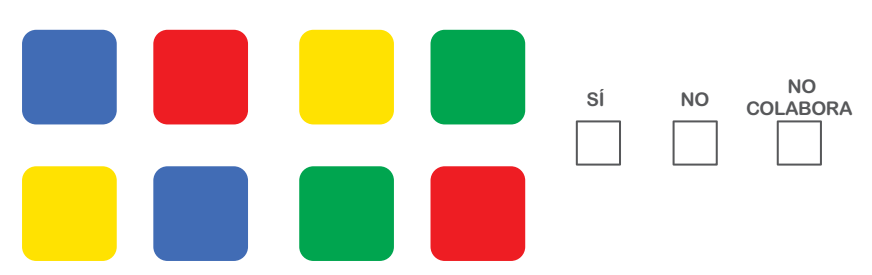

Uso oficial Pauta PRUNAPE No

4 - Entréguele el lápiz al niño o niña, déle las siguientes indicaciones y si pudo cumplirlas TODAS, marque sí.

•"poné el lápiz debajo de la silla", •"poné el lápiz delante de mis pies", •"poné el lápiz sobre la silla”.

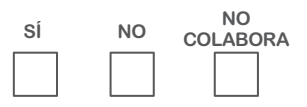

(17)

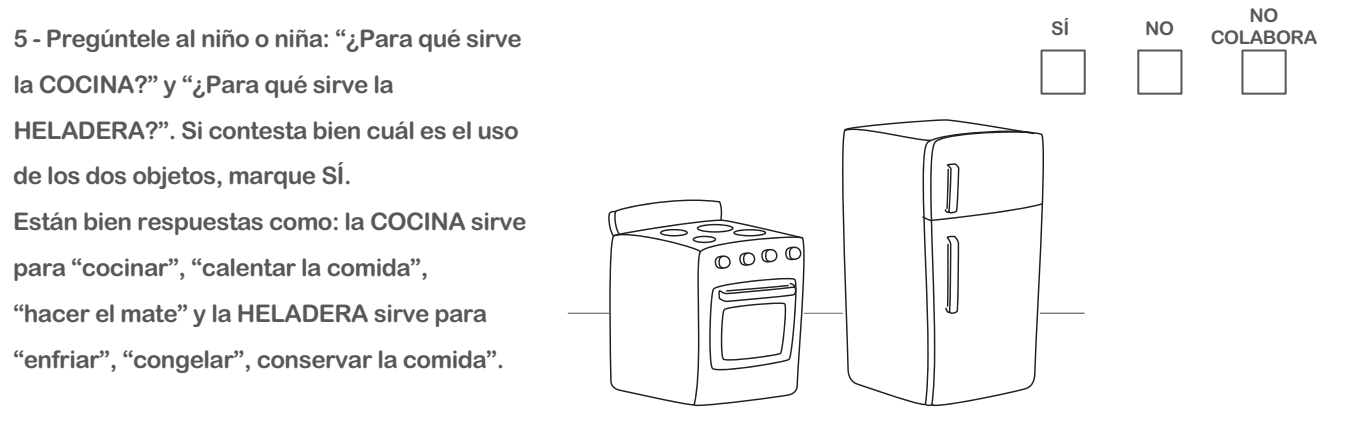

- Mostrame el rojo.

- Mostrame el amarillo.

- Mostrame el azul.
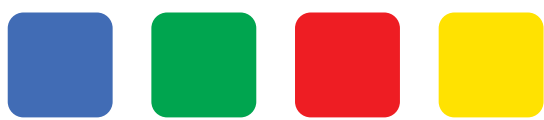

- Mostrame el verde.

Si el niño o niña señala tres o cuatro colores correctamente, marque Sí.

7 - Pregúntele al niño o niña: “¿Cómo te das cuenta cuándo es de DíA?” y

“¿Cómo te das cuenta cuándo es de NOCHE?”. Si contesta bien una de las preguntas o las dos, marque sí.

si

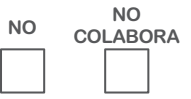

$(51)$

Están bien respuestas como: es de DíA porque "hay luz", "voy al jardín”,

“está el sol” y es de NOCHE porque "está oscuro", "están las estrellas", "está

la luna", "me voy a dormir". 


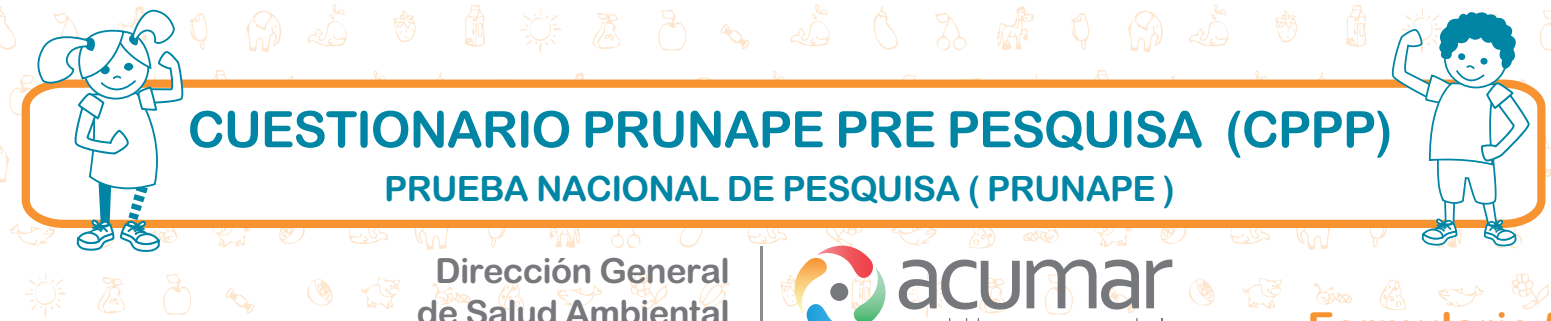
de Salud Ambiental $\bullet$ aCUMa

Formulario 5

Número de identificación: ..........................(uso oficial)

Niños y niñas de 4 años a 5 años y 11 meses

8 - Pídale al niño o niña que se pare en un solo pie sin apoyarse.

Muéstrele cómo hacerlo.

Déle dos o tres oportunidades y si puede hacerlo

sin caerse, marque sí.
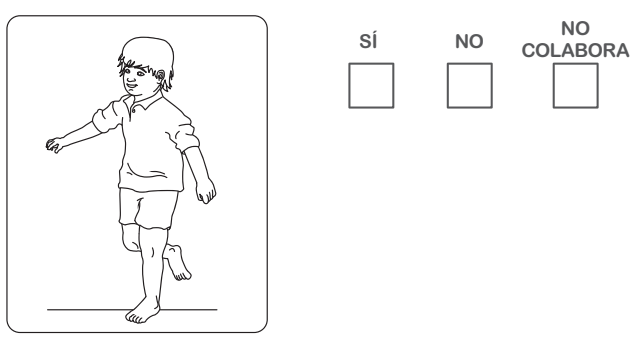

Uso oficial

Pauta PRUNAPE N

(75)

9 - Pídale al niño o niña que salte en un pie varias veces. Muéstrele cómo hacerlo,

y si el niño o niña puede hacerlo al menos dos veces

sin caerse, marque sí.
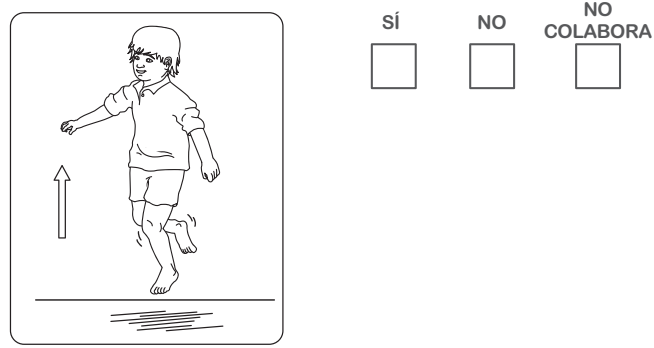

(77)

10 - Pídale al niño o niña que camine solo poniendo un pie delante del otro, de forma tal que el talón de un pie toque con la punta del otro, en una línea recta, como jugando a "pan y queso" y si puede dar algunos pasos sin caerse, marque Sí. Muéstrele al niño o

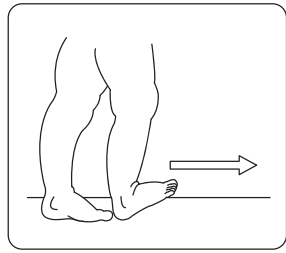

niña cómo hacerlo

11 - Pídale al niño o niña que haga lo mismo pero caminando hacia atrás poniendo un pie detrás del otro, de forma tal que la punta de un pie toque con el talón del otro y si puede dar algunos pasos sin caerse, marque sí. Muéstrele al niño o niña cómo hacerlo.

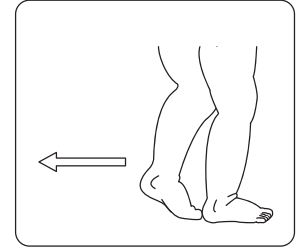

(79) 
Validation of a questionnaire for the detection of children at high risk of developmental disorders. The PRUNAPE Pre-Screening Test I 503

En las próximas preguntas usted deberá pedirle al niño o niña que dibuje. Léale las consignas. Usted NO deberá marcar ninguna respuesta.

12 - Pídale al niño o niña que copie con el lápiz la figura que se muestra debajo.

Uso oficial Pauta PRUNAPE N

(34)

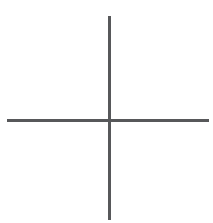

sí

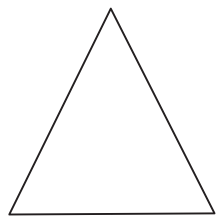

zona para dibujar

14 - Pídale al niño o niña que dibuje una persona (una mamá, un papá, un nene o una nena).

El espacio en blanco que sigue a continuación es para que el niñola haga su dibujo de la figura humana.

(33)

(3 partes)

$\square$ si

NO

NO 


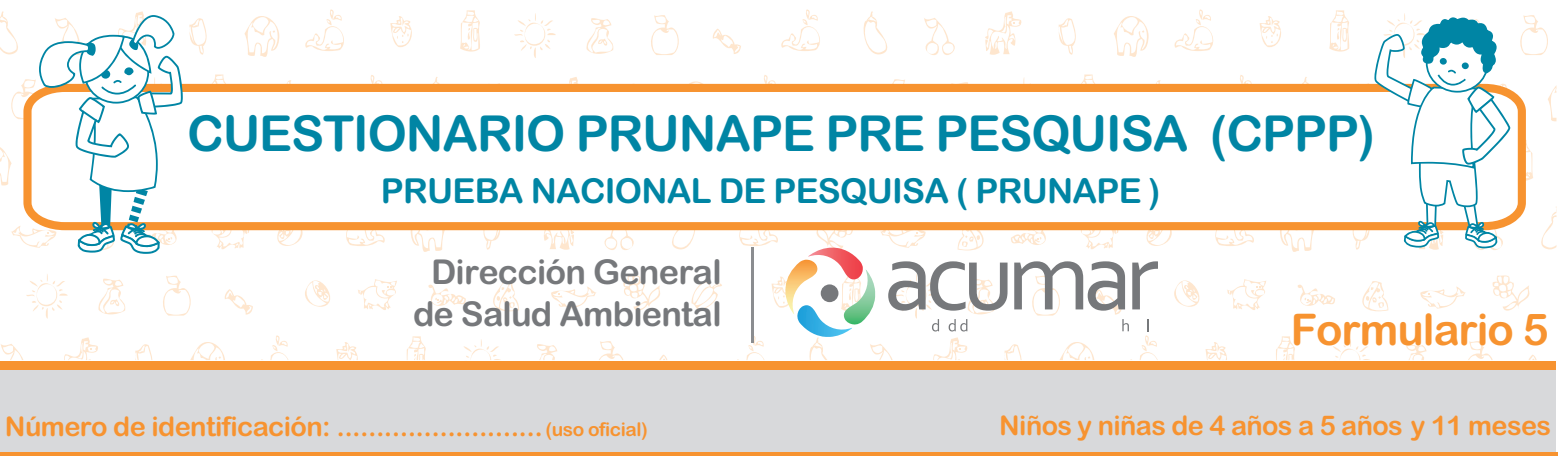

\section{Uso oficial: Resultados del CPPP - para ser completado por personal de salud.}

1- La edad del niño o niña es .............. meses............ días

2- Las preguntas a considerar aquí son aquellas cuyo percentil 75 es menor que la edad del niño o niña; márquela con una $X$ y luego tilde "CUMPLE" o "NO CUMPLE".

\begin{tabular}{|c|c|c|c|c|}
\hline Pregunta $\mathrm{N}^{\circ}$ & $\begin{array}{l}\text { Preguntas a } \\
\text { considerar }\end{array}$ & Percentil 75 & Cumple & $\begin{array}{c}\text { No Cumple, } \\
\text { (no sabe, no colabora) }\end{array}$ \\
\hline $1-$ & $\square$ & $36 \mathrm{~m} \mathrm{11d}$ & $\square$ & $\square$ \\
\hline $2-$ & $\square$ & $43 \mathrm{~m} 20 \mathrm{~d}$ & $\square$ & $\square$ \\
\hline $3-$ & $\square$ & $43 m 13 d$ & $\square$ & $\square$ \\
\hline $4-$ & $\square$ & $41 \mathrm{~m} 8 \mathrm{~d}$ & $\square$ & $\square$ \\
\hline $5-$ & $\square$ & $45 m 22 d$ & $\square$ & $\square$ \\
\hline $6-$ & $\square$ & $52 \mathrm{~m} 28 \mathrm{~d}$ & $\square$ & $\square$ \\
\hline $7-$ & $\square$ & $56 \mathrm{~m} 8 d$ & $\square$ & $\square$ \\
\hline 8- & $\square$ & $36 \mathrm{~m} 29 \mathrm{~d}$ & $\square$ & $\square$ \\
\hline 9- & $\square$ & $47 m \quad 12$ & $\square$ & $\square$ \\
\hline $10-$ & $\square$ & $52 \mathrm{~m} 10 \mathrm{~d}$ & $\square$ & $\square$ \\
\hline $11-$ & $\square$ & $63 \mathrm{~m} 11 d$ & $\square$ & $\square$ \\
\hline $12-$ & $\square$ & $50 \mathrm{~m} 19 \mathrm{~d}$ & $\square$ & $\square$ \\
\hline $13-$ & $\square$ & $66 \mathrm{~m} 11 \mathrm{~d}$ & $\square$ & $\square$ \\
\hline 14 - (3 partes) & $\square$ & $48 m 25 d$ & $\square$ & $\square$ \\
\hline 14 - (6 partes) & $\square$ & $58 \mathrm{~m} 24 \mathrm{~d}$ & $\square$ & $\square$ \\
\hline
\end{tabular}

El niño o niña no pasa el CPPP si la respuesta es NO CUMPLE en dos de las preguntas consideradas.

3-RESULTADO FINAL: PASA $\square$ NO PASA $\square$ (administrar PRUNAPE)

Nombre y apellido del agente de salud interviniente: ......

Lugar: . 